\title{
Trypanosoma cruzi transmission in the wild and its most important reservoir hosts in Brazil
}

\author{
Ana Maria Jansen*, Samanta Cristina das Chagas Xavier and André Luiz Rodrigues Roque
}

\begin{abstract}
Trypanosoma cruzi (Kinetoplastea: Trypanosomatidae) infects all tissues of its hosts, which along with humans, include hundreds of mammalian species in the Americas. The epidemiology of $T$. cruzi has been changing in that currently the majority of the cases and/or outbreaks of Chagas disease occur by the ingestion of comestibles contaminated by T. cruzi metacyclic forms. These cases/outbreaks occur in distinct regional scenarios, mainly in the Amazon biome and are related to the local interaction mode of humans with their surroundings, as well as with the overall local ecological peculiarities. As trypanosomiasis caused by T. cruzi is primarily a zoonosis, understanding the variables that influences its transmission in the wild as well as the role played by the extant fauna in the maintenance of the parasite, is critical in establishing control measures. Here, we present the results of our studies of $T$. cruzi infection of free ranging wild mammalian fauna in the five biomes of Brazil, a country of continental dimensions. From 1992 up to 2017, we examined a total of 6587 free-ranging non-volant wild mammal specimens. Our studies found that $17 \%$ of mammals were seropositive and $8 \%$ of all animals displayed positive hemocultures indicative of high parasitemia and, consequently, of infectivity potential. We observed that opossums, mainly Philander spp. and Didelphis spp., the coati Nasua nasua, the capuchin monkey Sapajus libidinosus and the golden lion tamarin Leontopithecus rosalia, were mammal taxa that demonstrated higher rates of positive hemocultures. Additionally, Didelphis spp. demonstrated to be a competent bioaccumulator of Tcl diversity. Chiroptera were distinguished for hosting the greatest diversity of species and genotypes of Trypanosoma spp. Additionally the observation of the higher host range of some Trypanosoma spp., shows the need to reassess the ecology of representatives of the taxon. Altogether, our results showed that each locality, may display distinct enzootiological and epidemiological scenarios that must be taken into account when it comes to establishing control and/or clarification campaigns of the local population.
\end{abstract}

Keywords: Trypanosoma cruzi, Wildlife reservoirs, Opossums, Primates, Carnivores, Transmission cycle

\section{Background}

The current rapid anthropogenic environmental changes, in addition to the uncontrolled human and animal migrations within an increasingly globalized world, act powerfully as parasite dispersers. This is the case of trypanosomiasis caused by $T$. cruzi that in humans can result in Chagas disease, currently considered a global health challenge [1].

Trypanosoma cruzi is a true generalist and highly successful parasite in that it is able to infect almost all cell

\footnotetext{
* Correspondence: jansen@ioc.fiocruz.br

Laboratório de Biologia de Tripanosomatídeos, Instituto Oswaldo Cruz/ FIOCRUZ, Av. Brasil 4365, Rio de Janeiro, RJ CEP. 21040-360, Brazil
}

types of hundreds of mammal species distributed from southern USA to the south of Argentina. This parasite species is transmitted by dozens of exclusively hematophagous triatomine bug species (insects of the order Hemiptera), in which the parasite establishes permanent infections. In its mammalian hosts, $T$. cruzi also establishes stable and long-lasting infections, that display peculiarities inherent to the different host species and even individuals and other multiple factors, such as the parasite subpopulations, infection route, host nutritional status and concomitant infection with distinct $T$. cruzi DTUs (discrete typing units) or other parasite taxa [2].

(c) The Author(s). 2018 Open Access This article is distributed under the terms of the Creative Commons Attribution 4.0 International License (http://creativecommons.org/licenses/by/4.0/), which permits unrestricted use, distribution, and 
Trypanosomiasis caused by $T$. cruzi is primarily an ancient enzootic parasitosis of wild mammals and its most probable main dispersion strategy in nature is the oral route, by predation on both infected vectors and mammals. Consequently, T. cruzi transmission in the wild is deeply immersed in trophic nets [2,3]. Additionally, the classical contaminative route by metacyclic forms eliminated in infected triatomine feces may frequently occur in animals in their shelters and nests. It is also probable that the contaminative transmission by metacyclic forms of the scent gland of didelphid marsupials [4] represents an efficient transmission mechanism in the wild, but this has not been evaluated so far. This transmission route could have been important in the wild before hemipterans developed hematophagic habits [5]. The competence to infect all mammalian nucleated cells in any tissue as well as the diverse infectious forms, also represent a powerful mechanism of the maintenance of $T$. cruzi in nature. In addition to these evolutionary advantages, T. cruzi also displays a huge biological plasticity, probably as the result of its impressive biological, biochemical and molecular heterogeneity. Understanding the origin of $T$. cruzi heterogeneity still represents a challenge: although the population structure of $T$. cruzi is mainly clonal, mitochondrial introgression and hybridization events occur intra and inter-T. cruzi DTUs [6]. The frequency with which these phenomena occur in nature and their importance as promoters of T. cruzi diversity has been a highly discussed issue for decades. Currently, the set of these T. cruzi subpopulations were subdivided into seven taxonomic units or DTUs, namely TcI-TcVI and Tcbat. The latter, formerly assumed as restricted to bats, has been described infecting pre-Columbian human mummies $[7,8]$. The attempts that have been made to associate a given subpopulation of the parasite with the distinct forms of human disease, the ecology of its wildlife host species, the biome of its occurrence and vector species have not yet resulted in conclusive associations. If any association exists between a given parasite subpopulation and specific symptoms of the disease or reservoir, only long-term studies of a representative number of $T$. cruzi isolates of representative mammalian species of the different biomes and habitats will establish this. Currently, however, studies have been conducted with samples that are obtained usually on only a single occasion from a single infected individual. These samples are then subjected to selective pressures inherent to isolation and maintenance methods. In addition, representative $T$. cruzi isolates of representative mammalian species present in all habitats where the parasite occurs are lacking. Altogether, we are sure that these gaps result in huge biases.

\section{After all, what constitutes a reservoir?}

Defining what constitutes a reservoir is a practical and theoretical challenge, and there are currently many definitions $[9,10]$. Our concept of a reservoir is based on that proposed by Ashford [11], according to which a reservoir, or rather a reservoir system, is the species or the assemblage of species that support the maintenance of a parasite in nature in a sustainable way in a given space scale. Actually, among the several definitions, this seems the best-fit for a complex taxon as in the case of T. cruzi. Indeed, this multi-host parasite establishes peculiar and dynamic interaction patterns with each of its hundreds of host species, which therefore play different roles in the parasite transmission network of the different habitats and biomes of its occurrence.

The host's capacity of being infective to its vectors, under natural conditions, depends on several factors, the most important being the concentration of parasites in the mammalian host's blood (i.e. the parasitemia). That is, a mammalian host displays its maximum infectivity potential during the period in which it maintains a sufficient amount of circulating parasites to be ingested during the blood meal of the vector, ensuring its dispersion and maintenance in nature. The periods of high parasitemia vary among host species and individuals. The currently known variables that determine the duration of parasitemia in a given animal species (or even individual) include at least parasite genotype, nutritional status, infection route and concomitant infection. A combinatorial analysis of all the variables might result in an infinite number of possibilities. The competence of a mammalian host in infecting vectors was elegantly termed by Brunner et al. [12] as "realized reservoir competence".

Among the points that should be taken into account when evaluating a given mammalian species as a reservoir, is its precise taxonomic classification. In fact, even cryptic species may present significant differences of the course of the infection with the same species of parasite as is the case of Thrichomys laurentius, a caviomorph rodent species of the semi-arid caatinga in northeast Brazil, and T. fosteri, a species from the Pantanal, a flood plain region in west-central Brazil. Experimental infections with $T$. cruzi in these two rodent species showed that $T$. fosteri demonstrated a significantly higher and long-lasting parasitemia and much more severe histopathological lesions [13]. These rodent species, which are morphologically absolutely indistinguishable, demonstrated to manage $T$. cruzi infection in totally different ways and consequently play a very different role in the maintenance of $T$. cruzi in the natural environment, as was later demonstrated $[14,15]$.

Evaluating the infectivity potential of a mammal species is a challenging task since it depends on a long-term follow-up of naturally or experimentally infected animals. In the latter case, the great challenge is the difficulty in rearing and maintaining wild mammal species in animal facilities. Experimental infections in conventional 
laboratory animal models are not representative and do not mimic infection conditions in the wild. In order to fully understand a reservoir system, it is important within the area of study to take an inventory of the local species, to analyse their population structure and to assess the taxonomic and beta diversity of an area.

One of the major obstacles to the study of wild reservoirs is the lack of species-specific reagents for serological tests. These tests are indispensable because they detect infected animals which have low, undetectable parasitemia, as shown by negative parasitological tests, i.e. low infectivity potential. Ideally two serological tests and two parasitological tests with distinct sensitivity should be employed.

In this review article, we summarize the data concerning wild reservoirs of $T$. cruzi collected during the last 20 years by our research group. We used data exclusively collected by our group as a way of making these data comparable. Moreover, we used the same techniques that we employed after establishing standard operating procedures (SOP) in our laboratory (Labtrip). The technical team, if renewed, received proper training by our staff before assuming any procedure as a way to maintain quality and repeatability. Thus, the methods employed in all steps were the same and are, therefore, comparable. In short: (i) blood cultures were performed in two tubes with $300 \mu \mathrm{l}$ of blood in each that were examined fortnightly for up to five months; (ii) serology was performed through indirect immunofluorescent assay tests (IFAT), according to Camargo [16] Epimastigotes of T. cruzi, strains F (DTU TcI) and Y (DTU TcII) were grown in NNN/LIT medium to exponential phase and subsequently washed. Whole epimastigotes of each strain were mixed in equal proportions and employed as antigen in the IFAT assays. The reaction was revealed by species or specific family conjugate]; and (iii) molecular characterization at the DTU-level by means of two algorithms, mini-exon with RFLP and, more recently, nested-PCR for the $18 S$ gene followed by sequence analysis. In this sense, all bat samples, as well as original isolates from other mammals not previously characterized in DTUs level, were recharacterized by the nested PCR protocol [17]. The complete methodology, as well as some of the results that were previously published, are described elsewhere [14, 15, 18-30].

Longitudinal studies are labor-intensive, logistically challenging and very expensive; however, they are the most informative. For example, in Brazil, the greatest infectivity potential of $T$. cruzi was observed in free-ranging wild Didelphimorphia (mainly Didelphis spp.), Primates and Carnivora. These observations were the result of 20 years of field studies in the different Brazilian biomes [14, 15, 18-30].

The infectivity potential, however, is not taxon-inherent and a fixed trait, as already mentioned above. A four-year study of the sylvatic transmission cycles of T. cruzi, performed in Argentina, concluded that cingulate and marsupials other than the genus Didelphis spp. displayed higher infectivity potential in comparison to Didelphis albiventris, classically described as the main $T$. cruzi reservoir [31]. Concerning domestic animals, dogs in Santiago del Estero (Argentina) demonstrated to be highly infective [32] in contrast to dogs in Brazil that rarely display high parasitemia [33, 34].

\section{The $T$. cruzi enzootic transmission cycle and its idiosyncrasies}

Trypanosoma cruzi enzootic transmission has been demonstrated to occur all over Brazil. Table 1 shows that $17 \%$ of the 6431 examined wild mammals had been exposed to $T$. cruzi infection as revealed by serological methods. Concerning Chiroptera, given their particularities, besides being the ancestral hosts and harboring numerous species of the T. cruzi clade, data referring this taxon are being presented in a separate table.

Positive hemocultures, i.e. infectivity potential, was observed in $8 \%$ of all 6587 examined animals distributed in all biomes. These data suggest that only $8 \%$ of individuals with infective competence are sufficient to maintain the widely dispersed and complex cycle of $T$. cruzi transmission. The lack of species-specific reagents impaired the performance of serological tests of all mammalian taxa. Even so, the sample of individuals that we were able to test was expressive and showed that $17 \%$ of them were seroreagent for $T$. cruzi showing that the infection of the majority of the infected mammals is expressed by positive serology $\left(\chi^{2}=197.36, d f=1, P<0.0001\right)$. It is worth noting that infected animals were distributed in all biomes. The rate (percentage) of mammals displaying positive blood cultures was considerably higher in the Amazon in comparison to the other biomes (Table 1).

All mammalian orders (Artiodactyla, Chiroptera, Primates, Carnivora, Rodentia, Cingulata, Pilosa and Didelphimorphia) demonstrated to be involved in the transmission cycle of $T$. cruzi to a greater or lesser degree and in distinct time- and space scales (Tables 2, 3, 4, 5, 6 and 7). Thus, the lowest number of infected mammals has been observed in the Cerrado, contrasting with the Amazon biome, where T. cruzi infection rates were the highest. The following taxa may be considered as key reservoir taxa due to the higher rates of parasitemia (as expressed by positive hemocultures) and competence in maintaining a higher diversity of $T$. cruzi DTUs, as well as other Trypanosoma species: Primates, Didelphimorphia, Chiroptera, and the Carnivora species Nasua nasua. Mixed T. cruzi DTU infections are frequent, notably in generalist (concerning habitats and feeding habits) mammal species [2]. That means that, besides environmental conditions (habitats, climate, 
Table 1 Trypanosoma cruzi natural infection in free-living wild mammals of Brazilian biomes: consolidated results showing the total number of non-volant mammalian orders, genera and species examined by blood cultures and serological tests (indirect immunofluorescence test, IFAT)

\begin{tabular}{|c|c|c|c|c|c|c|c|}
\hline Biomes & $\begin{array}{l}\text { No. of } \\
\text { orders }\end{array}$ & $\begin{array}{l}\text { No. of } \\
\text { genera }\end{array}$ & $\begin{array}{l}\text { No. of } \\
\text { species }\end{array}$ & $\begin{array}{l}\mathrm{HC}(+) / \text { specimens tested } \\
(\%)[95 \% \mathrm{Cl}]\end{array}$ & $\begin{array}{l}\text { IFAT(+)/ specimens tested } \\
\text { (\%) }[95 \% \mathrm{Cl}]\end{array}$ & $x^{2}$-value & $P$-value \\
\hline Amazon Forest & 7 & 33 & 31 & $\begin{array}{l}90 / 402(22) \\
{[18-26]}\end{array}$ & $\begin{array}{l}168 / 398(42) \\
{[37-47]}\end{array}$ & 35.968 & $<0.0001$ \\
\hline Atlantic Forest & 5 & 44 & 53 & $\begin{array}{l}205 / 2416(8) \\
{[7-9]}\end{array}$ & $\begin{array}{l}340 / 2375(14) \\
{[12-15]}\end{array}$ & 40.388 & $<0.0001$ \\
\hline Caatinga & 5 & 24 & 23 & $\begin{array}{l}99 / 1005(10) \\
{[8-11]}\end{array}$ & $\begin{array}{l}225 / 952(24) \\
{[20-26]}\end{array}$ & 67.235 & $<0.0001$ \\
\hline Cerrado & 7 & 54 & 67 & $\begin{array}{l}47 / 1973(2) \\
{[1,2]}\end{array}$ & $\begin{array}{l}191 / 1838(10) \\
{[10-12]}\end{array}$ & 132.321 & $<0.0001$ \\
\hline Pampa & 4 & 10 & 8 & 0 & 15/106 (14) & 16.142 & \\
\hline Pantanal & 5 & 27 & 19 & $\begin{array}{l}75 / 791(9) \\
{[7-11]}\end{array}$ & $\begin{array}{l}155 / 762(20) \\
{[17-23]}\end{array}$ & 36.278 & $<0.0001$ \\
\hline Total & & & & $516 / 6587(8)$ & $1094 / 6431(17)$ & 762.23 & $<0.0001$ \\
\hline
\end{tabular}

${ }^{\mathrm{a}} d f=1$

Difference between the rates of animals with positive blood cultures and positive serology among biomes were tested by ANOVA $(F=12.61, P=0.0075)$.

Comparison between the rates of animals with positive blood cultures and positive serology among biomes using Chi-square test $\left(\mathrm{HC}: X^{2}=34.532, d f=5\right.$, $P<0.000$; IFAT: $\left.X^{2}=30.36, d f=5, P<0.0001\right)$.

Abbreviations: $\mathrm{Cl}$, confidence interval; $\mathrm{HC}(+)$, number of specimens with positive hemocultures; IFAT(+), number of specimens with positive IFAT test

anthropogenic influence, etc.) both diversity and faunal composition are indicators of a more or less robust $T$. cruzi transmission cycle in a given area.

The T. cruzi infection rate of free-living mammals in the Amazon biome was significantly higher than observed in other biomes, both in relation to blood cultures and serology (IFAT). Free living mammals of Caatinga, Pantanal and Atlantic forest displayed comparable rates of positive hemocultures (Table $1 ; P<0.0001$ ). Moreover, the distribution of T. cruzi DTUs in Brazilian biomes is apparently non-homogeneous. As an example, the DTU TcII that was rarely found in the Amazon and even then, in localities that are distant from each other (Table 2). This observation raises the question of how is a T. cruzi DTU that is only sporadically isolated, maintained and dispersed in the natural environment? Actually, there is still much to learn about the ecology of $T$. cruzi and its DTUs.

In the Cerrado, most trapped and examined mammals were rodents $(54.6 \%)$ (Table 5). Primates accounted for only $2.3 \%$ of the examined mammals, while marsupials and carnivores constituted 27.4 and $15.6 \%$ of sampled animals, respectively (Table 5 ). Only $2 \%$ of all examined mammals displayed positive hemocultures in this biome, which was statiscally different from other biomes (Table 1; $P<0.0001)$.

It is worth noting that although the number of examined mammals and study areas is large, these are still not representative considering the huge diversity and number of the extant mammalian fauna and the huge ecological diversity and dimensions of the country. It was not possible for our group to test all of the examined wild mammal species by serological methods due to the lack of species-specific conjugates and/or insufficient amount of serum. Actually, blood cannot be collected from very small-sized animals in sufficient quantities for blood cultures (one pair of tubes with 300 $\mu \mathrm{l}$ each) and serology (50 $\mu \mathrm{l}$ sera).

\section{Trypanosoma cruzi transmission among mammals with low parasitemia}

In the Pampa biome, 14\% of the animals demonstrated positive serology but none displayed positive blood culture (Table 6). The questions that immediately arise are: how is transmission possible as it depends on high parasitaemia, and what is the strategy that ensures the permanence of the parasite in this scenario? In contrast, in the Amazon, 22\% of mammals including those using all forest strata presented high parasitaemia expressed by positive blood cultures in a classical epizootic scenario (Table 2). A hypothesis we favor is that the mammal fauna in the Pampa display only short periods of high parasitaemia, i.e. the transmission window of these individuals is narrow, and it is the assemblage of mammals at different stages of infection that ensures the persistence of T. cruzi in nature [2]. In areas in which mammalian fauna display low parasitemia, the transmission of $T$. cruzi may also rely on ecological features of hosts and triatomine, e.g. in higher host-vector contact as is the case of nesting animal species such as coatis, hoary foxes and golden lion tamarins.

The overall low T. cruzi infection rates observed in the order Rodentia that are highly susceptible to experimental infection suggest that these mammals play a secondary role as reservoirs in the wild (Tables 2, 3, 4, 5, 6, 7 and 8). This was especially striking in the Cerrado 
Table 2 Trypanosoma cruzi natural infection in free-living wild mammals from the Amazon Forest biome: taxonomic identification of the examined mammals, results of hemocultures, indirect immunofluorescence tests and characterization of parasites. In the case of insufficient blood for hemocultures and serological tests, we prioritized the blood cultures

\begin{tabular}{|c|c|c|c|c|c|c|c|}
\hline Order & Genus & Species & $\begin{array}{l}\text { No. of } \\
\text { genera }(\%)^{a}\end{array}$ & $\begin{array}{l}\text { No. of } \\
\text { specimens }\end{array}$ & $\begin{array}{l}\mathrm{HC}(+) / \text { specimens } \\
\text { tested }(\%)\end{array}$ & $\begin{array}{l}\text { IFAT(+)/ specimens } \\
\text { tested (\%) }\end{array}$ & DTU (n) \\
\hline Artiodactyla & Sus & Sus scrofa & 11 & 11 & 0 & $8(73)$ & \\
\hline \multirow[t]{3}{*}{ Cingulata } & Dasypus & $\begin{array}{l}\text { Dasypus } \\
\text { novemcinctus }\end{array}$ & $1 / 3(33)$ & 1 & $1(100)$ & nd & TcIV (1) \\
\hline & & Dasypus sp. & & 2 & 0 & nd & \\
\hline & Euphractus & $\begin{array}{l}\text { Euphractus } \\
\text { sexcinctus }\end{array}$ & 1 & 1 & 0 & nd & \\
\hline \multirow[t]{17}{*}{ Didelphimorphia } & Caluromys & $\begin{array}{l}\text { Caluromys } \\
\text { philander }\end{array}$ & 2/8 (25) & 1 & 0 & $1(100)$ & \\
\hline & & Caluromys sp. & & 7 & $2(29)$ & $3(43)$ & $\mathrm{TCl}(1)$ \\
\hline & Didelphis & $\begin{array}{l}\text { Didelphis } \\
\text { albiventris }\end{array}$ & $24 / 64(37)$ & 4 & 0 & 0 & \\
\hline & & $\begin{array}{l}\text { Didelphis } \\
\text { marsupialis }\end{array}$ & & 58 & $24(41)$ & $44(76)$ & $\begin{array}{l}\text { TCl (16); TCll (1); TCl+T. rangeli (1); } \\
\text { Tcl+Tcll (2); TCl+Tclll (1); } \\
\text { T. rangeli (1) }\end{array}$ \\
\hline & & Didelphis sp. & & 2 & 0 & $1(50)$ & \\
\hline & Gracilinanus & Gracilinanus sp. & 1/17 (6) & 17 & $1(6)$ & $2(12)$ & $\mathrm{TCl}(1)$ \\
\hline & Marmosa & $\begin{array}{l}\text { Marmosa } \\
\text { murina }\end{array}$ & 25 & 7 & 0 & $2(29)$ & $\mathrm{TCl}(1)$ \\
\hline & & Marmosa sp. & & 18 & 0 & $3(16)$ & \\
\hline & Marmosops & $\begin{array}{l}\text { Marmosops } \\
\text { parvidens }\end{array}$ & 1/12 (8) & 1 & 0 & $1(100)$ & \\
\hline & & Marmosops sp. & & 11 & $1(9)$ & $3(27)$ & $\mathrm{TCl}(1)$ \\
\hline & Metachirus & $\begin{array}{l}\text { Metachirus } \\
\text { nudicaudatus }\end{array}$ & 6 & 6 & 0 & 0 & \\
\hline & Micoureus & $\begin{array}{l}\text { Micoureus } \\
\text { demerarae }\end{array}$ & $1 / 9(11)$ & 2 & $1(50)$ & $1(50)$ & $\mathrm{TCl}(1)$ \\
\hline & & Micoureus sp. & & 7 & 0 & 0 & \\
\hline & Monodelphis & $\begin{array}{l}\text { Monodelphis } \\
\text { domestica }\end{array}$ & 2/12 (16) & 7 & 0 & $1(14)$ & \\
\hline & & Monodelphis sp. & & 5 & $2(40)$ & $2(40)$ & $\mathrm{TCl}(1) ; \mathrm{Tcl}+\mathrm{TcIV}(1)$ \\
\hline & Philander & $\begin{array}{l}\text { Philander } \\
\text { opossum }\end{array}$ & 23/67 (34) & 57 & $18(32)$ & $42(74)$ & $\begin{array}{l}\text { TCl (14); } T \mathrm{Cl}+\mathrm{TCll}(2) ; \\
\text { T. rangeli (1) }\end{array}$ \\
\hline & & Philander sp. & & 10 & $5(50)$ & $7(70)$ & $\begin{array}{l}\text { TCl (3); TCl+TCIII/TCIV (1); } \\
\text { Tcl+T. rangeli (1) }\end{array}$ \\
\hline Lagomorpha & Sylvilagus & $\begin{array}{l}\text { Sylvilagus } \\
\text { brasiliensis }\end{array}$ & 1 & 1 & 0 & nd & \\
\hline Pilosa & Tamandua & $\begin{array}{l}\text { Tamandua } \\
\text { mirim }\end{array}$ & $1 / 2(50)$ & 2 & $1(50)$ & nd & $\mathrm{TCl}(1)$ \\
\hline \multirow[t]{3}{*}{ Primates } & Alouatta & $\begin{array}{l}\text { Alouatta } \\
\text { belzubul }\end{array}$ & $3 / 11(27)$ & 6 & $2(33)$ & $6(100)$ & Tcl+TclV (2) \\
\hline & & $\begin{array}{l}\text { Alouatta } \\
\text { caraya }\end{array}$ & & 5 & $1(20)$ & $2(40)$ & Tcl+TclV (1) \\
\hline & Sapajus & $\begin{array}{l}\text { Sapajus } \\
\text { libidinosus }\end{array}$ & $25 / 46(54)$ & 46 & $25(54)$ & $10(22)$ & $\begin{array}{l}\text { Tcl (2); } T \mathrm{Cl}+T \text {. rangeli }(10) ; \\
\text { T. rangeli (4) }\end{array}$ \\
\hline \multirow[t]{3}{*}{ Rodentia } & Akodon & Akodon sp. & $1 / 8(12)$ & 7 & 0 & 0 & \\
\hline & & $\begin{array}{l}\text { Akodon } \\
\text { lindberghi }\end{array}$ & & 1 & $1(100)$ & 0 & $\mathrm{Tcl}(1)$ \\
\hline & Cerradomys & Cerradomys sp. & 1 & 1 & 0 & $1(100)$ & \\
\hline
\end{tabular}


Table 2 Trypanosoma cruzi natural infection in free-living wild mammals from the Amazon Forest biome: taxonomic identification of the examined mammals, results of hemocultures, indirect immunofluorescence tests and characterization of parasites. In the case of insufficient blood for hemocultures and serological tests, we prioritized the blood cultures (Continued)

\begin{tabular}{|c|c|c|c|c|c|c|c|}
\hline Order & Genus & Species & $\begin{array}{l}\text { No. of } \\
\text { genera }(\%)^{\mathrm{a}}\end{array}$ & $\begin{array}{l}\text { No. of } \\
\text { specimens }\end{array}$ & $\begin{array}{l}\mathrm{HC}(+) / \text { specimens } \\
\text { tested }(\%)\end{array}$ & $\begin{array}{l}\text { IFAT(+)/ specimens } \\
\text { tested }(\%)\end{array}$ & DTU $(n)$ \\
\hline & Coendou & $\begin{array}{l}\text { Coendou } \\
\text { prehensilis }\end{array}$ & $2 / 6(33)$ & 6 & $2(33)$ & $4(67)$ & $\mathrm{Tcl}+$ T. rangeli (1) \\
\hline & \multirow[t]{2}{*}{ Dasyprocta } & $\begin{array}{l}\text { Dasyprocta } \\
\text { prymnolopha }\end{array}$ & 3 & 2 & 0 & $1(50)$ & \\
\hline & & Dasyprocta sp. & & 1 & 0 & 0 & \\
\hline & Euryoryzomys & Euryoryzomys sp. & 1 & 1 & 0 & 0 & \\
\hline & Holochilus & Holochilus sp. & 1 & 1 & 0 & $1(100)$ & \\
\hline & \multirow[t]{2}{*}{ Hylaeamys } & $\begin{array}{l}\text { Hylaeamys } \\
\text { megacephalus }\end{array}$ & 11 & 4 & $1(25)$ & $1(25)$ & $\mathrm{TCl}(1)$ \\
\hline & & Hylaeamys sp. & & 7 & 0 & 0 & \\
\hline & Mus & Mus musculus & 1 & 1 & 0 & 0 & \\
\hline & \multirow[t]{2}{*}{ Necromys } & $\begin{array}{l}\text { Necromys } \\
\text { lasiurus }\end{array}$ & 3 & 2 & 0 & 0 & \\
\hline & & Necromys sp. & & 1 & 0 & 0 & \\
\hline & \multirow[t]{2}{*}{ Nectomys } & Nectomys rattus & 6 & 4 & 0 & 0 & \\
\hline & & Nectomys sp. & & 2 & 0 & 0 & \\
\hline & Oecomys & Oecomys sp. & 4 & 4 & 0 & 0 & \\
\hline & Oligoryzomys & Oligoryzomys sp. & 1 & 1 & 0 & 0 & \\
\hline & Oryzomys & Oryzomys sp. & 10 & 10 & 0 & $1(10)$ & \\
\hline & Oxymycterus & Oxymycterus sp. & 3 & 3 & 0 & $2(67)$ & \\
\hline & \multirow[t]{5}{*}{ Proechimys } & $\begin{array}{l}\text { Proechimys } \\
\text { roberti }\end{array}$ & 2/47 (4) & 3 & 0 & $3(100)$ & \\
\hline & & Proechimys sp. & & 40 & $1(3)$ & $13(33)$ & Tcl+TcIII/TcIV (1) \\
\hline & & $\begin{array}{l}\text { Proechimys } \\
\text { gr. cuvieri }\end{array}$ & & 2 & $1(50)$ & $1(50)$ & $\mathrm{TCl}(1)$ \\
\hline & & $\begin{array}{l}\text { Proechimys } \\
\text { gr. goeldii }\end{array}$ & & 1 & 0 & 0 & \\
\hline & & $\begin{array}{l}\text { Proechimys } \\
\text { gr. guianensis }\end{array}$ & & 1 & 0 & $1(100)$ & \\
\hline Total: 7 & 31 & & & 401 & $90 / 402(22)$ & $168 / 398(42)$ & $P<0.0001$ \\
\hline
\end{tabular}

${ }^{a}$ Number of genera with infected species/number of genera examined

Abbreviations: $\mathrm{HC}(+)$, number of specimens with positive hemocultures; IFAT(+), number of specimens with positive IFAT test; DTU, Discrete Typing Units; $\mathrm{n}$, number of isolates; $\mathrm{nd}$, not done

biome, as expressed by their low infection rates $(3.7 \%$ of positive serological tests and $0.7 \%$ of positive hemocultures) (Table 5). Two hypotheses may explain these findings: (i) the infected animals do not resist the infection and die; or (ii) rodents are not exposed to infection in the studied Cerrado regions. Finally, these findings are similar to what was observed in the Pantanal biome [15] and support the hypothesis that, in fact, wild rodents only exceptionally play an important role as T. cruzi reservoirs.

The miscellaneous, focal and aggregated character of the $T$. cruzi transmission cycle in the wild environment can be observed in two biomes. In the Atlantic Forest, of the $8.5 \%$ of the mammals showing positive blood cultures, $44.4 \%$ were constituted by two species of tamarins: $37.6 \%$ by Didelphis spp. and $10.7 \%$ by Philander spp. Overall, in the Atlantic Forest, only $0.35 \%$ of the rodents displayed positive blood cultures (Table 7). In the Caatinga, we observed one rodent species (Rattus rattus) with high rates of positive blood cultures (21\%, Table 3 ), showing how important it is to look at every forest fragment as a singularity. Transmission patterns may change in time as revealed by studies of Trypanosoma spp. infection in coatis of a Pantanal region termed Nhecolandia. Initially, high rates of infection with $T$. evansi were observed (Table 4) [35]. The continued monitoring of this same coati population resulted in successful isolations of $T$. cruzi and also T. rangeli [30]. More recently, 
Table 3 Trypanosoma cruzi natural infection in free-living wild mammals from the Caatinga biome: taxonomic identification of the examined mammals, results of hemocultures, indirect immunofluorescence tests, and characterization of parasites. In the case of insufficient blood for hemocultures and serological tests, we prioritized the blood cultures

\begin{tabular}{|c|c|c|c|c|c|c|c|}
\hline Order & Genus & Species & $\begin{array}{l}\text { No. } \\
\text { genera (\%) }\end{array}$ & $\begin{array}{l}\text { No. of } \\
\text { specimens }\end{array}$ & $\begin{array}{l}\mathrm{HC}(+) / \text { specimens } \\
\text { tested }(\%)\end{array}$ & $\begin{array}{l}\text { IFAT(+)/ specimens } \\
\text { tested }(\%)\end{array}$ & DTU $(n)$ \\
\hline \multirow[t]{2}{*}{ Artiodactyla } & Pecari & Pecari tajacu & 1 & 1 & 0 & 0 & \\
\hline & Sus & Sus scrofa & 1 & 1 & 0 & 0 & \\
\hline \multirow[t]{2}{*}{ Carnivora } & Conepatus & $\begin{array}{l}\text { Conepatus } \\
\text { semistriatus }\end{array}$ & 3 & 3 & 0 & 0 & \\
\hline & Cerdocyon & $\begin{array}{l}\text { Cerdocyon } \\
\text { thous }\end{array}$ & 1 & 1 & 0 & 0 & \\
\hline \multirow[t]{2}{*}{ Cingulata } & Dasypus & $\begin{array}{l}\text { Dasypus } \\
\text { novemcinctus }\end{array}$ & $1 / 2(50)$ & 2 & $1(50)$ & nd & TcIII (1) \\
\hline & Euphractus & $\begin{array}{l}\text { Euphractus } \\
\text { sexcinctus }\end{array}$ & 51 & 51 & 0 & nd & \\
\hline \multirow[t]{9}{*}{ Didelphimorphia } & Didelphis & $\begin{array}{l}\text { Didelphis } \\
\text { albiventris }\end{array}$ & 49/134 (36) & 127 & $49(39)$ & $67(53)$ & $\begin{array}{l}\text { Tcl (34); TCl+T. rangeli (1); } \\
\text { Tcll+TcVN }(2) ; \text { T. rangeli (1) }\end{array}$ \\
\hline & & Didelphis sp. & & 7 & 0 & $4(57)$ & \\
\hline & Gracilinanus & Gracilinanus agilis & 26 & 13 & 0 & $2(15)$ & \\
\hline & & Gracilinanus sp. & & 13 & 0 & 0 & \\
\hline & Marmosops & $\begin{array}{l}\text { Marmosops } \\
\text { incanus }\end{array}$ & 10 & 10 & 0 & 0 & \\
\hline & Monodelphis & $\begin{array}{l}\text { Monodelphis } \\
\text { domestica }\end{array}$ & 7/94 (7) & 80 & $6(8)$ & $9(11)$ & $\begin{array}{l}\text { Tcl (1); TcIV (1); Tcl+T. rangeli } \\
\text { (1) }\end{array}$ \\
\hline & & Monodelphis sp. & & 14 & $1(7)$ & $2(14)$ & nd \\
\hline & Thylamys & Thylamys velutinus & 2 & 1 & 0 & 0 & \\
\hline & & Thylamys sp. & & 1 & 0 & 0 & \\
\hline \multirow[t]{17}{*}{ Rodentia } & Calomys & Calomys expulsus & 10 & 9 & 0 & 0 & \\
\hline & & Calomys sp. & & 1 & 0 & 0 & \\
\hline & Galea & Galea spixii & $1 / 47(2)$ & 38 & $1(3)$ & 0 & \\
\hline & & Galea sp. & & 9 & 0 & 0 & \\
\hline & Kerodon & Kerodon rupestris & 2 & 2 & 0 & 0 & \\
\hline & Mus & Mus musculus & $1 / 15(7)$ & 15 & $1(7)$ & $1(7)$ & nd \\
\hline & Necromys & Necromys lasiurus & 14 & 14 & 0 & 0 & \\
\hline & Oligoryzomys & Oligoryzomys sp. & 8 & 8 & 0 & $1(13)$ & \\
\hline & Oryzomys & $\begin{array}{l}\text { Oryzomys aff. } \\
\text { subflavus }\end{array}$ & 13 & 13 & 0 & 0 & \\
\hline & Proechimys & Proechimys sp. & 2 & 2 & 0 & 0 & \\
\hline & Rattus & Rattus rattus & 15/71 (21) & 71 & $15(21)$ & $49(69)$ & Tcl (10); Tcll (1) \\
\hline & Rhipidomys & $\begin{array}{l}\text { Rhipidomys } \\
\text { macrurus }\end{array}$ & 26 & 24 & 0 & $8(33)$ & \\
\hline & & Rhipidomys sp. & & 2 & 0 & 0 & \\
\hline & Thrichomys & $\begin{array}{l}\text { Thrichomys } \\
\text { laurentius }\end{array}$ & $25 / 466(5)$ & 434 & $23(5)$ & $72(17)$ & $\operatorname{TcV}(1) ; \operatorname{Tcl}+\operatorname{TcIV}(1) ; \operatorname{TcIV}(2)$ \\
\hline & & $\begin{array}{l}\text { Thrichomys } \\
\text { inermis }\end{array}$ & & 15 & 0 & $6(40)$ & \\
\hline & & $\begin{array}{l}\text { Thrichomys } \\
\text { apereoides }\end{array}$ & & 5 & $1(20)$ & $2(40)$ & nd \\
\hline & & Thrichomys sp. & & 12 & 1 (8) & $1(8)$ & nd \\
\hline
\end{tabular}


Table 3 Trypanosoma cruzi natural infection in free-living wild mammals from the Caatinga biome: taxonomic identification of the examined mammals, results of hemocultures, indirect immunofluorescence tests, and characterization of parasites. In the case of insufficient blood for hemocultures and serological tests, we prioritized the blood cultures (Continued)

\begin{tabular}{|c|c|c|c|c|c|c|c|}
\hline Order & Genus & Species & $\begin{array}{l}\text { No. } \\
\text { genera }(\%)^{\mathrm{a}}\end{array}$ & $\begin{array}{l}\text { No. of } \\
\text { specimens }\end{array}$ & $\begin{array}{l}\mathrm{HC}(+) / \text { specimens } \\
\text { tested }(\%)\end{array}$ & $\begin{array}{l}\text { IFAT(+)/ specimens } \\
\text { tested (\%) }\end{array}$ & DTU (n) \\
\hline & Trinomys & Trinomys sp. & 1 & 1 & 0 & 0 & \\
\hline & Wiedomys & $\begin{array}{l}\text { Wiedomys } \\
\text { pyrrhorhinos }\end{array}$ & 5 & 3 & 0 & $1(33)$ & \\
\hline & & Wiedomys sp. & & 2 & 0 & 0 & \\
\hline Total: 5 & 24 & & & 1005 & $99 / 1005(10)$ & $225 / 952(24)$ & $P<0.0001$ \\
\hline
\end{tabular}

${ }^{a}$ Number of genera with infected species/number of genera examined

Abbreviations: $\mathrm{HC}(+)$, number of specimens with positive hemocultures; IFAT(+), number of specimens with positive IFAT test; DTU, Discrete Typing Units; $\mathrm{n}$, number of isolates; nd, not done

coatis demonstrated to be again infected with T. evansi and to a lesser extent with $T$. cruzi or T. rangeli [2]. It is tempting to hypotethize that climatic alterations resulted in this process, but which ones? Trypanosoma evansi and T. cruzi display distinct transmission strategies T. evansi being mechanically transmitted by hematophagous dipterans and $T$. cruzi and $T$. rangeli, by triatomine vectors. All these data together show that host-parasite systems are complex and unpredictable.

An example of independent transmission cycles occurring in the same forest fragment was observed in a rainforest fragment in the Atlantic Forest biome where a conservation program of the endangered golden lion tamarin (GLT) species, Leontophithecus rosalia, is maintained [25]. The study of T. cruzi infection of GLTs and sympatric mammals revealed that only GLTs were infected with T. cruzi DTU TcII and all other species of local mammals showed infections with TcI (Table 7) [25].

Of the examined infected mammals, those species that demonstrated the higher infectivity potential, as expressed by high rates of positive hemocultures throughout Brazilian biomes will be highlighted here. These mammal taxa are Didelphimorphia (Didelphis spp. and Philander spp.), procyonid carnivores ( $N$. nasua) and primates (Table 8). It is worth mentioning that representatives of the Didelphimorphia displayed the highest infective competence in the Amazon, Atlantic Forest and Caatinga (along with primates in the first two biomes). In the Pantanal, $N$. nasua plays this role. Bats were distinguished for presenting the highest diversity of Trypanosoma spp. infection in simple and mixed infections and are discussed separately (Table 9).

Didelphimorphia (Didelphis spp. and Philander spp.) Marsupials comprise a mammal group which presents a peculiar reproduction strategy. These ancient mammals are an evolutionary success since they are extant, with little anatomical change since the Cretaceous [36]. The family Didelphidae includes all representatives of metatherian mammals or marsupials extant in the Americas. Didelphidae includes four subfamilies (Glironiinae,
Caluromyniae, Hyladelphinae and Didelphinae), 19 genera and 95 species of which only four do not occur in South America [37].

The species within the genus Didelphis include the largest American marsupials. Didelphis spp. have a pair of scent glands adjacent to the cloaca that are a suitable niche for the multiplication of $T$. cruzi as epimastigote forms and for its differentiation to infective metacyclic trypomastigotes [4]. Didelphid marsupials have a very short gestation time (in Didelphidae, delivery occurs on average after 13 days of gestation). Individuals are born in an almost embryonic stage; the newborns do not have obvious eyes, ears or hind legs. They are absolutely hairless, and their mouth is a small hole through which the newborn will adhere to a nipple, and to which it will remain attached and totally dependent for six to eight weeks. Nevertheless, the newborn marsupial must climb from the womb without maternal aid to reach the pouch and adhere to a nipple. At this stage, and for the next several weeks, the newborn is totally dependent on the marsupium, and if removed will not survive. Despite the close and long contact between the newborn with the mother, in experimental conditions, we never observed neonatal transmission of T. cruzi in D. aurita [38].

Often described as essentially arboreal, Didelphis spp. use with reasonable frequency the soil, the understory, and the sub-canopy/canopy strata. However, the use of vertical space is not a fixed trait; it depends on the population structure, in that competition between young and adult animals may determine the level of occupation of the vertical space. Interspecific competition may also determine the use of the vertical space by this taxon [39]. In the wild, Didelphis spp. also use tree hollows, wood piles, palm crown and other locations for shelter, all of which are excellent habitats for triatomine species. Didelphidae are classically described as solitary animals with social interactions restricted to the mating season and to young pouch animals. However, this paradigm is being challenged by recent observations suggesting that these animals may display a social behavior pattern [40]. 
Table 4 Trypanosoma cruzi natural infection in free-living wild mammals from the Pantanal biome: taxonomic identification of the examined mammals, results of hemocultures, indirect immunofluorescence tests (IFAT), and characterization of parasites. In the case of insufficient blood for hemocultures and serological tests, we prioritized the blood cultures

\begin{tabular}{|c|c|c|c|c|c|c|c|}
\hline Order & Genus & Species & $\begin{array}{l}\text { No. of } \\
\text { genera }(\%)^{\mathrm{a}}\end{array}$ & $\begin{array}{l}\text { No. of } \\
\text { specimens }\end{array}$ & $\begin{array}{l}\mathrm{HC}(+) / \\
\text { specimens tested (\%) }\end{array}$ & $\begin{array}{l}\text { IFAT(+)/ } \\
\text { specimens tested (\%) }\end{array}$ & DTU $(n)$ \\
\hline \multirow[t]{3}{*}{ Artiodactyla } & Sus & Sus scrofa & $1 / 9(11)$ & 9 & $1(11)$ & 0 & TCIII (1) \\
\hline & Tayassu & $\begin{array}{l}\text { Tayassu } \\
\text { tajacu }\end{array}$ & 32 & 4 & 0 & 0 & \\
\hline & & $\begin{array}{l}\text { Tayassu } \\
\text { pecari }\end{array}$ & & 28 & 0 & 0 & \\
\hline \multirow[t]{4}{*}{ Carnivora } & Cerdocyon & $\begin{array}{l}\text { Cerdocyon } \\
\text { thous }\end{array}$ & $3 / 114(3)$ & 96 & 0 & $53(55)$ & \\
\hline & Leopardus & $\begin{array}{l}\text { Leopardus } \\
\text { pardalis }\end{array}$ & 28 & 28 & 0 & $3(11)$ & \\
\hline & Nasua & $\begin{array}{l}\text { Nasua } \\
\text { nasua }\end{array}$ & 49/189 (26) & 189 & $49(26)$ & $52(28)$ & $\begin{array}{l}\text { T. rangeli (2); TCl (33); T } \\
\mathrm{Cl}+\text { T. rangeli (4); TCl+Tcll (5); } \\
\text { TCll (1); Tcll+T. rangeli (1) }\end{array}$ \\
\hline & Procyon & $\begin{array}{l}\text { Procyon } \\
\text { cancrivorus }\end{array}$ & 2/15 (13) & 15 & $2(13)$ & $9(60)$ & $\mathrm{TCl}(1)$ \\
\hline \multirow[t]{4}{*}{ Cingulata } & Cabassous & $\begin{array}{l}\text { Cabassous } \\
\text { unicinctus }\end{array}$ & 3 & 3 & 0 & nd & \\
\hline & Dasypus & $\begin{array}{l}\text { Dasypus } \\
\text { novemcinctus }\end{array}$ & $2 / 2(100)$ & 2 & $2(100)$ & nd & TCIII (2) \\
\hline & Euphractus & $\begin{array}{l}\text { Euphractus } \\
\text { sexcinctus }\end{array}$ & $1 / 14(7)$ & 14 & $1(7)$ & nd & TCIII (1) \\
\hline & Priodontes & $\begin{array}{l}\text { Priodontes } \\
\text { maximus }\end{array}$ & 10 & 10 & 0 & nd & \\
\hline \multirow[t]{9}{*}{ Didelphimorphia } & Didelphis & $\begin{array}{l}\text { Didelphis } \\
\text { albiventris }\end{array}$ & 2 & 2 & 0 & $1(50)$ & \\
\hline & Gracilinanus & $\begin{array}{l}\text { Gracilinanus } \\
\text { agilis }\end{array}$ & 4/17 (23) & 3 & $3(100)$ & 0 & $\mathrm{Tcl}(2) ; \mathrm{Tcl}+\mathrm{Tcll}(1)$ \\
\hline & & Gracilinanus sp. & & 14 & $1(7)$ & 0 & $\mathrm{Tcl}(1)$ \\
\hline & Marmosa & Marmosa sp. & $1 / 5(20)$ & 5 & $1(20)$ & $1(20)$ & nd \\
\hline & Marmosops & Marmosops sp. & 1 & 1 & 0 & 0 & \\
\hline & Monodelphis & Monodelphis sp. & 2/14 (14) & 7 & $1(14)$ & $1(14)$ & nd \\
\hline & & $\begin{array}{l}\text { Monodelphis } \\
\text { domestica }\end{array}$ & & 7 & $1(14)$ & 0 & $\mathrm{TCl}(1)$ \\
\hline & Philander & $\begin{array}{l}\text { Philander } \\
\text { frenatus }\end{array}$ & $1 / 1(100)$ & 1 & $1(100)$ & 0 & Tcl+TcIV (1) \\
\hline & Thylamys & Thylamys sp. & 2/11 (18) & 11 & $2(18)$ & $1(9)$ & $\mathrm{Tcl}(2)$ \\
\hline \multirow[t]{9}{*}{ Rodentia } & Calomys & Calomys sp. & 6 & 6 & 0 & 0 & \\
\hline & Cerradomys & Cerradomys sp. & 10 & 10 & 0 & 0 & \\
\hline & Clyomys & Clyomys laticeps & 39 & 2 & 0 & $2(100)$ & \\
\hline & & Clyomys sp. & & 37 & 0 & 0 & \\
\hline & Dasyprocta & $\begin{array}{l}\text { Dasyprocta } \\
\text { azarae }\end{array}$ & 8 & 3 & 0 & 0 & \\
\hline & & Dasyprocta sp. & & 5 & 0 & $2(40)$ & \\
\hline & Holochilus & Holochilus sp. & 2 & 2 & 0 & 0 & \\
\hline & Marmosa & Marmosa sp. & 1 & 1 & 0 & 0 & \\
\hline & Oecomys & $\begin{array}{l}\text { Oecomys } \\
\text { mamorae }\end{array}$ & 9/34 (26) & 34 & $9(100)$ & 0 & TCl (5); TcIV (3) \\
\hline
\end{tabular}


Table 4 Trypanosoma cruzi natural infection in free-living wild mammals from the Pantanal biome: taxonomic identification of the examined mammals, results of hemocultures, indirect immunofluorescence tests (IFAT), and characterization of parasites. In the case of insufficient blood for hemocultures and serological tests, we prioritized the blood cultures (Continued)

\begin{tabular}{|c|c|c|c|c|c|c|c|}
\hline Order & Genus & Species & $\begin{array}{l}\text { No. of } \\
\text { genera }(\%)^{a}\end{array}$ & $\begin{array}{l}\text { No. of } \\
\text { specimens }\end{array}$ & $\begin{array}{l}\mathrm{HC}(+) / \\
\text { specimens tested (\%) }\end{array}$ & $\begin{array}{l}\text { IFAT(+)/ } \\
\text { specimens tested (\%) }\end{array}$ & DTU $(n)$ \\
\hline & Oryzomys & Oryzomys sp. & 19 & 19 & 0 & $4(21)$ & \\
\hline & Thrichomys & $\begin{array}{l}\text { Thrichomys } \\
\text { fosteri }\end{array}$ & $2 / 216(1)$ & 138 & $2(1)$ & $3(2)$ & $\mathrm{Tcl}(1) / / \mathrm{TcIV}(1)$ \\
\hline & & Thrichomys sp. & & 78 & 0 & $23(29)$ & \\
\hline & Thylamys & Thylamys sp. & 7 & 7 & 0 & 0 & \\
\hline Total: 5 & 27 & & & 791 & 75/791 (9) & 155/762 (20) & $P<0.0001$ \\
\hline
\end{tabular}

${ }^{a}$ Number of genera with infected species/number of genera examined

Abbreviations: $\mathrm{HC}(+)$, number of specimens with positive hemocultures; IFAT(+), number of specimens with positive IFAT test; DTU, Discrete Typing Units; $\mathrm{n}$, number of isolates; nd, not done

Didelphid marsupials are nocturnal, nomadic (mainly the males) and are agile climbers but quite clumsy when on the ground. Didelphis spp. can become infected orally (preying on small mammals or triatomines); they display high infectivity potential mainly for TcI (with high levels of parasitaemia almost indefinitely) and are able to infect other mammals directly in antagonistic situations as T. cruzi could be present in the secretions from the scent glands that are released by stress.

Trypanosoma cruzi is not homogeneously distributed in the lumen of the scent glands. The epimastigotes are found along the glandular epithelium that is coated by hyaluronic acid. The metacyclic forms are found mainly in the middle of the lumen of the glands and metacyclogenesis occurs regardless of adhesion [41]. This ensures the preferential elimination of infectious trypomastigotes when scent glands are used. All these characteristics have, as a consequence, that didelphids are exposed to all of the T. cruzi transmission cycles that occur in these habitats.

Didelphis spp. are extremely habitat and food resilient and easily adapt to peri-domestic areas. There, they feed on human food remains and also serve as food for humans. This is especially the case among the riverine settlements in the Amazon rainforest. Besides being an important source of protein, Didelphis spp. are also used for medicinal purposes by these populations; the meat is described as tasty and of good quality [42]. The preparation of opossums without the proper care of hygiene also represents a T. cruzi infection risk to humans.

Marsupials of the genus Philander are smaller than Didelphis spp. Philander spp. are extremely agile on the ground and also display remarkable climbing ability. They are also described as the most aggressive didelphids. These opossums are exclusively nocturnal and, although often caught on the soil, they are also arboreal. They live in dense forests or underbrush where they build their nests of leaves but may also eventually use branches or fallen trunks as shelter. Their preferred environments appear to be gallery forests or other more humid environmetns, where they are often found. Philander spp. display quite eclectic feeding habits and predate both on insects and small vertebrates, including mammals. They also feed on fruits and eggs.

Due to their nomadic character, generalist feeding and housing habits, Philander spp. and Didelphis spp. are exposed to T. cruzi transmission cycles occurring in all forest strata in the wild. Interestingly, species of these two genera of marsupials handle experimental infections with T. cruzi differently. Thus, Didelphis spp. control to subpatent levels infections with the $\mathrm{Y}$ strain of T. cruzi (TcII) but maintain indefinitely high parasitaemias (expressed by positive blood cultures) in infections with TcI strains. In contrast, Philander spp. maintain high parasitaemia when inoculated with strain Y (TcII) and control the parasitemia with TcI strains [43]. TcI and TcII are, however, found in mixed infections, and this is the most common and most widely dispersed combination that we found infecting both mammals and vectors [2].

As shown in Table 8, Didelphis spp. and Philander spp. demonstrated high rates of positive blood cultures in the Atlantic Forest and the Amazon. In the semi-arid region of the north-eastern Brazil. Didelphis spp. act as an important reservoir. In the Pantanal, in addition to being uninfected, the relative abundance of these two species was very low. In this immense flood plain region, the primary reservoir of T. cruzi is the procyonid N. nasua.

A very interesting and puzzling finding was reported by Dario et al. [44] who observed one Monodelphis americana (Didelphimorphia) specimen infected simultaneously with T. cascavelli, T. dionisii and Trypanosoma sp. Trypanosoma cascavelli was originally described infecting a Crotalus durissus terrificus [45]. There are three interesting aspects here: (i) the infection of a marsupial with a Trypanosoma species associated exclusively to bats ( $T$. dionisii); (ii) a Trypanosoma species that is able to infect both a mammal and a reptile in a mixed infection with $T$. dionisii; and (iii) the presence of a still unknown taxonomic unit of Trypanosoma sp. Concerning the second 
Table 5 Trypanosoma cruzi natural infection in free-living wild mammals from the Cerrado biome: taxonomic identification of the examined mammals, results of hemocultures, indirect immunofluorescence tests (IFAT), and characterization of parasites. In the case of insufficient blood for hemocultures and serological tests, we prioritized the blood cultures

\begin{tabular}{|c|c|c|c|c|c|c|c|}
\hline Order & Genus & Species & $\begin{array}{l}\text { No. of } \\
\text { genera (\%) }\end{array}$ & $\begin{array}{l}\text { No. of } \\
\text { specimens }\end{array}$ & $\begin{array}{l}\mathrm{HC}(+) / \text { specimens } \\
\text { tested }(\%)\end{array}$ & $\begin{array}{l}\text { IFAT(+)/ specimens } \\
\text { tested }(\%)\end{array}$ & DTU $(n)$ \\
\hline Artiodactyla & Pecari & Pecari tajacu & 1 & 1 & 0 & 0 & \\
\hline \multirow[t]{10}{*}{ Carnivora } & Cerdocyon & Cerdocyon thous & 59 & 59 & 0 & $22(37)$ & \\
\hline & Chrysocyon & $\begin{array}{l}\text { Chrysocyon } \\
\text { brachyurus }\end{array}$ & 91 & 91 & 0 & $6(6)$ & \\
\hline & Conepatus & $\begin{array}{l}\text { Conepatus } \\
\text { semistriatus }\end{array}$ & 2 & 2 & 0 & nd & \\
\hline & Eira & Eira barbara & 5 & 5 & 0 & nd & \\
\hline & Leopardus & Leopardus pardalis & $2 / 3(67)$ & 3 & $2(67)$ & $1(33)$ & $\mathrm{Tcl}(2)$ \\
\hline & Lontra & Lontra longicaudis & 1 & 1 & 0 & nd & \\
\hline & Lutra & Lutra longicaudis & 1 & 1 & 0 & nd & \\
\hline & Nasua & Nasua nasua & 3 & 3 & 0 & nd & \\
\hline & Puma & Puma concolor & 2 & 2 & 0 & $2(100)$ & \\
\hline & Pseudalopex & $\begin{array}{l}\text { Pseudalopex } \\
\text { vetulus }\end{array}$ & 3/74 (4) & 48 & $2(4)$ & $22(46)$ & TCIII (2); \\
\hline \multirow[t]{3}{*}{ Cingulata } & Cabassous & $\begin{array}{l}\text { Cabassous } \\
\text { unicinctus }\end{array}$ & 2 & 2 & 0 & nd & \\
\hline & Dasypus & $\begin{array}{l}\text { Dasypus } \\
\text { novemcinctus }\end{array}$ & 2 & 2 & 0 & nd & \\
\hline & Euphractus & $\begin{array}{l}\text { Euphractus } \\
\text { sexcinctus }\end{array}$ & 5 & 5 & 0 & nd & \\
\hline \multirow[t]{18}{*}{ Didelphimorphia } & Caluromys & $\begin{array}{l}\text { Caluromys } \\
\text { philander }\end{array}$ & $1 / 10(10)$ & 10 & $1(10)$ & 0 & $\mathrm{TCl}(1)$ \\
\hline & Chironectes & $\begin{array}{l}\text { Chironectes } \\
\text { minimus }\end{array}$ & 4 & 4 & 0 & 0 & \\
\hline & Cryptonanus & $\begin{array}{l}\text { Cryptonanus } \\
\text { agricolai }\end{array}$ & 3 & 3 & 0 & 0 & \\
\hline & Didelphis & $\begin{array}{l}\text { Didelphis } \\
\text { albiventris }\end{array}$ & 9/118 (7) & 104 & $9(9)$ & $30(29)$ & $\mathrm{TCl}(4)$ \\
\hline & & Didelphis sp. & & 14 & 0 & $4(29)$ & \\
\hline & Gracilinanus & Gracilinanus agilis & 10/191 (5) & 92 & $2(2)$ & $5(5)$ & $\mathrm{TCl}(2)$ \\
\hline & & Gracilinanus sp. & & 99 & $8(8)$ & $14(14)$ & $\begin{array}{l}\text { TCl (4); TCl+TCIII/TCIV (3); } \\
\text { TCl+TCIV (1) }\end{array}$ \\
\hline & Lutreolina & $\begin{array}{l}\text { Lutreolina } \\
\text { crassicaudata }\end{array}$ & 1 & 1 & 0 & 0 & \\
\hline & Marmosa & Marmosa murina & 59 & 38 & 0 & $1(4)$ & \\
\hline & & Marmosa sp. & & 21 & 0 & 0 & \\
\hline & Micoureus & $\begin{array}{l}\text { Micoureus } \\
\text { demerarae }\end{array}$ & 2/11 (18) & 3 & 0 & 0 & \\
\hline & & $\begin{array}{l}\text { Micoureus } \\
\text { travassosi }\end{array}$ & & 4 & $2(50)$ & $3(75)$ & $\mathrm{TCl}(2)$ \\
\hline & & Micoureus sp. & & 4 & 0 & 0 & \\
\hline & Monodelphis & $\begin{array}{l}\text { Monodelphis } \\
\text { cf. americana }\end{array}$ & 4/121 (3) & 1 & 0 & 0 & \\
\hline & & $\begin{array}{l}\text { Monodelphis } \\
\text { domestica }\end{array}$ & & 93 & $2(2)$ & $1(1)$ & TCIII (1) \\
\hline & & Monodelphis kunsi & & 2 & 0 & 0 & \\
\hline & & Monodelphis sorex & & 1 & 0 & 0 & \\
\hline & & Monodelphis sp. & & 24 & $2(8)$ & 0 & $\mathrm{Tcl}(2)$ \\
\hline
\end{tabular}


Table 5 Trypanosoma cruzi natural infection in free-living wild mammals from the Cerrado biome: taxonomic identification of the examined mammals, results of hemocultures, indirect immunofluorescence tests (IFAT), and characterization of parasites. In the case of insufficient blood for hemocultures and serological tests, we prioritized the blood cultures (Continued)

\begin{tabular}{|c|c|c|c|c|c|c|c|}
\hline Order & Genus & Species & $\begin{array}{l}\text { No. of } \\
\text { genera (\%) }\end{array}$ & $\begin{array}{l}\text { No. of } \\
\text { specimens }\end{array}$ & $\begin{array}{l}\mathrm{HC}(+) / \text { specimens } \\
\text { tested }(\%)\end{array}$ & $\begin{array}{l}\text { IFAT(+)/ specimens } \\
\text { tested }(\%)\end{array}$ & DTU $(n)$ \\
\hline & Philander & Philander sp. & 2 & 2 & 0 & $1(50)$ & \\
\hline & Thylamys & Thylamys sp. & 2 & 2 & 0 & 0 & \\
\hline \multirow[t]{2}{*}{ Pilosa } & Myrmecophaga & $\begin{array}{l}\text { Myrmecophaga } \\
\text { tridactyla }\end{array}$ & 3 & 3 & 0 & nd & \\
\hline & Tamandua & $\begin{array}{l}\text { Tamandua } \\
\text { tetradactyla }\end{array}$ & 2 & 2 & 0 & nd & \\
\hline \multirow[t]{4}{*}{ Primates } & Alouatta & Alouatta caraya & 5 & 5 & 0 & $1(20)$ & \\
\hline & Callithrix & Callithrix penicillata & 3 & 3 & 0 & $1(33)$ & \\
\hline & Cebus & Cebus apella & 35 & 33 & 0 & $9(27)$ & \\
\hline & & Cebus sp. & & 2 & 0 & $1(50)$ & \\
\hline \multirow[t]{28}{*}{ Rodentia } & Akodon & Akodon montensis & $2 / 51(4)$ & 1 & 0 & 0 & \\
\hline & & Akodon sp. & & 50 & $2(4)$ & 0 & $\mathrm{TCl}(2)$ \\
\hline & Brucepattersonius & Brucepattersonius sp. & 8 & 8 & 0 & 0 & \\
\hline & Calomys & Calomys expulsus & $3 / 286(1)$ & 51 & 0 & 0 & \\
\hline & & Calomys tener & & 39 & $1(3)$ & $1(3)$ & $\mathrm{TCl}(1)$ \\
\hline & & Calomys sp. & & 196 & $2(1)$ & $6(3)$ & $\mathrm{Tcl}(2)$ \\
\hline & Cerradomys & $\begin{array}{l}\text { Cerradomys } \\
\text { maracajuensis }\end{array}$ & $1 / 28(3)$ & 5 & 0 & 0 & \\
\hline & & $\begin{array}{l}\text { Cerradomys } \\
\text { marinhus }\end{array}$ & & 9 & 0 & $1(11)$ & \\
\hline & & $\begin{array}{l}\text { Cerradomys } \\
\text { megacephalus }\end{array}$ & & 1 & 0 & 0 & \\
\hline & & Cerradomys scotti & & 6 & 0 & 0 & \\
\hline & & Cerradomys subflavus & & 7 & $1(14)$ & 0 & $\mathrm{TCl}(1)$ \\
\hline & & Cerradomys sp. & & 27 & $2(7)$ & $1(4)$ & $\mathrm{TCl}(2)$ \\
\hline & Dasyprocta & Dasyprocta azarae & 3 & 2 & 0 & nd & \\
\hline & & Dasyprocta sp. & & 1 & 0 & nd & \\
\hline & Hydrochoerus & $\begin{array}{l}\text { Hydrochoerus } \\
\text { hydrochaeris }\end{array}$ & 2 & 2 & 0 & 0 & \\
\hline & Hylaeamys & $\begin{array}{l}\text { Hylaeamys } \\
\text { megacephalus }\end{array}$ & 3/108 (3) & 51 & $3(6)$ & $3(6)$ & nd \\
\hline & & Hylaeamys sp. & & 57 & 0 & 0 & \\
\hline & Juliomys & Juliomys sp. & 1 & 1 & 0 & 0 & \\
\hline & Mus & Mus musculus & 1 & 1 & 0 & 0 & \\
\hline & Necromys & Necromys lasiurus & 171 & 166 & 0 & $1(0.6)$ & \\
\hline & & Necromys sp. & & 5 & 0 & $2(40)$ & \\
\hline & Nectomys & Nectomys rattus & 45 & 28 & 0 & $7(25)$ & \\
\hline & & Nectomys squamipes & & 3 & 0 & 0 & \\
\hline & & Nectomys sp. & & 13 & 0 & 0 & \\
\hline & Oecomys & Oecomys bicolor & 2/94 (2) & 27 & $2(7)$ & 0 & \\
\hline & & Oecomys concolor & & 10 & 0 & 0 & \\
\hline & & Oecomys sp. & & 57 & 0 & $3(5)$ & \\
\hline & Oligoryzomys & Oligoryzomys fornesi & $2 / 175(1)$ & 16 & 0 & 0 & \\
\hline
\end{tabular}


Table 5 Trypanosoma cruzi natural infection in free-living wild mammals from the Cerrado biome: taxonomic identification of the examined mammals, results of hemocultures, indirect immunofluorescence tests (IFAT), and characterization of parasites. In the case of insufficient blood for hemocultures and serological tests, we prioritized the blood cultures (Continued)

\begin{tabular}{|c|c|c|c|c|c|c|c|}
\hline Order & Genus & Species & $\begin{array}{l}\text { No. of } \\
\text { genera (\%) }\end{array}$ & $\begin{array}{l}\text { No. of } \\
\text { specimens }\end{array}$ & $\begin{array}{l}\mathrm{HC}(+) / \text { specimens } \\
\text { tested }(\%)\end{array}$ & $\begin{array}{l}\text { IFAT(+)/ specimens } \\
\text { tested (\%) }\end{array}$ & DTU $(n)$ \\
\hline & & $\begin{array}{l}\text { Oligoryzomys } \\
\text { moojeni }\end{array}$ & & 3 & 0 & 0 & \\
\hline & & Oligoryzomys nigripes & & 8 & 0 & 0 & \\
\hline & & Oligoryzomys sp. & & 148 & $2(1)$ & $3(2)$ & Tcll (1) \\
\hline & Oryzomys & Oryzomys subflavus & 42 & 1 & 0 & 0 & \\
\hline & & $\begin{array}{l}\text { Oryzomys } \\
\text { megacephalus }\end{array}$ & & 15 & 0 & $4(27)$ & \\
\hline & & Oryzomys scotti & & 2 & 0 & $1(50)$ & \\
\hline & & Oryzomys sp. & & 24 & 0 & $3(13)$ & \\
\hline & Oxymycterus & Oxymycterus sp. & 9 & 9 & 0 & $1(11)$ & \\
\hline & Proechimys & Proechimys roberti & 42 & 25 & 0 & $1(4)$ & \\
\hline & & Proechimys sp. & & 17 & 0 & $2(12)$ & \\
\hline & Rattus & Rattus norvegicus & $1 / 15(7)$ & 2 & 0 & 0 & \\
\hline & & Rattus rattus & & 13 & $1(8)$ & $7(54)$ & nd \\
\hline & Rhipidomys & $\begin{array}{l}\text { Rhipidomys cf. } \\
\text { mastacalis }\end{array}$ & $1 / 26(4)$ & 9 & 0 & 0 & \\
\hline & & $\begin{array}{l}\text { Rhipidomys } \\
\text { macrurus }\end{array}$ & & 2 & 0 & 0 & \\
\hline & & Rhipidomys sp. & & 15 & $1(7)$ & $5(33)$ & nd \\
\hline & Sooretamys & Sooretamys sp. & 1 & 1 & 0 & 0 & \\
\hline & Sphiggurus & Sphiggurus sp. & 1 & 1 & 0 & 0 & \\
\hline & Thrichomys & $\begin{array}{l}\text { Thrichomys } \\
\text { aff. inermis }\end{array}$ & 41 & 7 & 0 & $2(29)$ & \\
\hline & & $\begin{array}{l}\text { Thrichomys } \\
\text { apereoides }\end{array}$ & & 2 & 0 & 0 & \\
\hline & & Thrichomys sp. & & 32 & 0 & $9(28)$ & \\
\hline & Wiedomys & Wiedomys sp. & 2 & 2 & 0 & 0 & \\
\hline Total: 7 & 52 & & & 1973 & 47/1973 (2) & 191/1838 (10) & $P<0.0001$ \\
\hline
\end{tabular}

${ }^{a}$ Number of genera with infected species/number of genera examined

Abbreviations: $\mathrm{HC}(+)$, number of specimens with positive hemocultures; IFAT(+), number of specimens with positive IFAT test; DTU, Discrete Typing Units; $\mathrm{n}$, number of isolates; nd, not done

item, Didelphimorphia display lower temperatures in comparison to other mammalian taxa, a feature that could enhance the adaptation chances of $T$. cascavelli to this mammal taxon. Moreover, transmission may be due to a hematophagous insect that feeds on both marsupials and snakes, or due to predation of Monodelphis spp. by Crotalus sp. Actually, Monodelphis spp. are small-sized marsupials that definitively are not able to feed on rattlesnakes. These findings were only possible because Dario et al. used NGS since $T$. cascavelli is not cultivable in axenic media. As such, it is clear that we are still underestimating the diversity of Trypanosoma spp. in marsupials.

The infection of marsupials with $T$. dionisii reinforces this species as a generalist species, since this parasite was already found infecting humans [18]. Actually, humans, bats and marsupials are phylogenetically very distant taxa.

\section{The coati, N. nasua, and other carnivores}

Working with carnivores is not easy and requires a complex infrastructure and well-trained experienced professionals. This might explain why most studies of reservoirs of $T$. cruzi do not include representatives of this group. Most carnivores are adapted to terrestrial life, but they may also be excellent swimmers and climbers. Carnivores use large living areas, are at the top of the food chain and are talented hunters. Consequently, it is very probable that these animals are more prone to infection via the oral route. Not all carnivores are flesh eaters sensu stricto. There are opportunistic carnivore species that also feed on insects and fruits. Only the 
Table 6 Trypanosoma cruzi natural infection in free-living wild mammals from the Pampa biome: taxonomic identification of the examined mammals and indirect immunofluorescence tests (IFAT)

\begin{tabular}{|c|c|c|c|c|c|}
\hline Order & Genus & Species & No. of genera (\%) & No. of specimens & IFAT(+)/ specimens tested (\%) \\
\hline \multirow[t]{3}{*}{ Carnivora } & Cerdocyon & Cerdocyon thous & 2 & 2 & $1(50)$ \\
\hline & Leopardus & Leopardus geoffroyi & 1 & 1 & 0 \\
\hline & Pseudalopex & Pseudalopex gymnocercus & 4 & 4 & $3(75)$ \\
\hline Didelphimorphia & Didelphis & Didelphis albiventris & 26 & 26 & $8(31)$ \\
\hline Primates & Alouatta & Alouatta sp. & 2 & 2 & nd \\
\hline \multirow[t]{5}{*}{ Rodentia } & Akodon & Akodon sp. & 2 & 2 & 0 \\
\hline & Mus & Mus musculus & 40 & 40 & 0 \\
\hline & Rattus & Rattus rattus & 2 & 1 & $1(100)$ \\
\hline & Scapteromys & Scapteromys aquaticus & 28 & 28 & $2(7)$ \\
\hline & Sooretamys & Sooretamys angouya & 2 & 2 & 0 \\
\hline Total & 10 & 8 & & 108 & 15/106 (14) \\
\hline
\end{tabular}

Abbreviations: IFAT(+), number of specimens with positive IFAT test; nd, not done

so-called hypercarnivore (majority of the felids) depend almost exclusively on flesh.

All carnivores, including domestic dogs and cats, may be involved in the transmission cycle of $T$. cruzi [32, 33, 46]. Concerning wild carnivores, infection with T. cruzi was demonstrated in 15 Brazilian Neotropical wild carnivore species [3]. A link between diet peculiarities and T. cruzi infection rates in these taxa could also be observed. Thus, insectivore canids and hypercarnivores (those that include flesh as more than $70 \%$ of their diet) displayed higher T. cruzi infection rates than other carnivores with other types of diet. These findings confirmed that T. cruzi transmission cycles are deeply immersed in the trophic nets. Additionally, differences in infectivity potential across the carnivore species have also been described the Procyonids, mainly N. nasua, N. narica and Procyon lotor, being the carnivore species that display the more expressive infectiveness potential as expressed by high and long-lasting parasitemias [3, 27, 47-49]. Note that Procyonids are omnivores that also feed on both insects and small mammals [50], a trait that enhances their chances of infection with the diverse T. cruzi DTUs.

Coatis are scansorial, diurnal and generalist procyonid carnivores that use both the arboreal and terrestrial strata $[50,51]$. They are peculiar mammals in that they construct and use arboreal nests for resting and birthing [52]. One individual may use several nests during its lifespan, or more than one individual or even a whole social group may share the same resting nest. This behavior increases the probability of encounter between coatis and triatomines, since bugs also use these nests as shelter, consequently enhancing $T$. cruzi transmission chances. Nasua nasua are organized in social groups that include mainly females and young, still immature individuals, and only a few adult males [53]. The birthing nests are constructed by the females that give birth to up to seven pups. In these nests, which are larger than the resting nests, the female remains caring for her cubs for about two months [51, 52].

Encounter rates between free-ranging mammals and vectors are one of the most important and challenging variables to be determined. Actually, animal shelters and nests may be used successively, by several species of living organisms, including triatomine vectors of $T$. cruzi. Coatis arboreal nests offer shelter for several other animal taxa, forming genuine and complex biocenoses. On dissection, these nests can be found to contain ants, lizards, beetles and triatomines. Arboreal nests of coatis have also been demonstrated to be suitable habitats for Rhodnius stalii and Triatoma sordida, which were described living in sympatry, in a same arboreal coati's nest. Even a terrestrial rodent has been described visiting a coati's nest [54]. Probably, this rodent used fallen trunks or vines to reach the nest that was over ten meters above the ground. This report shows that the detection of a particular $T$ cruzi DTU in an individual mammalian host species does not necessarily mean that there is an association between the DTU and that species or forest stratum.

During a study of coati ecology, Santos et al. [55] collected Triatoma sordida $(n=13)$ and Rhodnius stali $(n=2)$ from seven coati resting nests. Additionally, 21 nymphs of all stages were collected from these nests, confirming these as suitable habitats for triatomines. Seventeen isolates of $T$. cruzi derived from insects of four coati nests were obtained, mostly TcI. One single insect was found infected with TcIII, and four individuals displayed mixed infections with TcI and TcIII. The use of these nests by coatis and other animals provides a suitable habitat for the maintenance of the triatome colonies since sufficient food source and shelter is offered. 
Table 7 Trypanosoma cruzi natural infection in free-living wild mammals from the Atlantic Forest biome: taxonomic identification of the examined mammals, results of hemocultures, indirect immunofluorescence tests (IFAT), and characterization of parasites. In the case of insufficient blood for hemocultures and serological tests, we prioritized the blood cultures

\begin{tabular}{|c|c|c|c|c|c|c|c|}
\hline Order & Genus & Species & $\begin{array}{l}\text { No. of } \\
\text { genera }(\%)^{a}\end{array}$ & $\begin{array}{l}\text { No. of } \\
\text { specimens }\end{array}$ & $\begin{array}{l}\mathrm{HC}(+) / \\
\text { specimens tested (\%) }\end{array}$ & $\begin{array}{l}\text { IFAT(+)/ } \\
\text { specimens tested (\%) }\end{array}$ & DTU $(n)$ \\
\hline \multirow[t]{7}{*}{ Carnivora } & Cerdocyon & Cerdocyon thous & 1 & 1 & 0 & 0 & \\
\hline & Galictis & Galictis vittata & $1 / 2(50)$ & 1 & $1(100)$ & nd & TCIII (1) \\
\hline & & Galictis cuja & & 1 & 0 & nd & \\
\hline & Leopardus & $\begin{array}{l}\text { Leopardus } \\
\text { pardalis }\end{array}$ & 4 & 2 & 0 & $2(100)$ & \\
\hline & & $\begin{array}{l}\text { Leopardus } \\
\text { tigrinus }\end{array}$ & & 2 & 0 & $2(100)$ & \\
\hline & Procyon & Procyon cancrivorus & 2 & 2 & 0 & 0 & \\
\hline & Puma & $\begin{array}{l}\text { Puma } \\
\text { yagouaroundi }\end{array}$ & 2 & 2 & 0 & $1(50)$ & \\
\hline \multirow[t]{3}{*}{ Cingulata } & Dasypus & $\begin{array}{l}\text { Dasypus } \\
\text { septemcinctus }\end{array}$ & 4 & 1 & 0 & nd & \\
\hline & & $\begin{array}{l}\text { Dasypus } \\
\text { novemcinctus }\end{array}$ & & 1 & 0 & nd & \\
\hline & & Dasypus sp. & & 2 & 0 & nd & \\
\hline \multirow[t]{17}{*}{ Didelphimorphia } & Didelphis & $\begin{array}{l}\text { Didelphis } \\
\text { albiventris }\end{array}$ & 77/409 (19) & 44 & $2(5)$ & $11(25)$ & nd \\
\hline & & Didelphis aurita & & 271 & $69(25)$ & $81(30)$ & 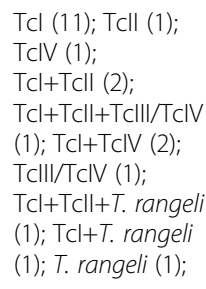 \\
\hline & & Didelphis sp. & & 94 & $6(6)$ & $19(20)$ & nd \\
\hline & Gracilinanus & $\begin{array}{l}\text { Gracilinanus } \\
\text { microtarsus }\end{array}$ & 7 & 1 & 0 & 0 & \\
\hline & & Gracilinanus sp. & & 6 & 0 & 0 & \\
\hline & Marmosa & $\begin{array}{l}\text { Marmosa } \\
\text { paraguayana }\end{array}$ & 6 & 1 & 0 & 0 & \\
\hline & & Marmosa sp. & & 8 & 0 & $3(37)$ & \\
\hline & Marmosops & $\begin{array}{l}\text { Marmosops } \\
\text { incanus }\end{array}$ & 2/14 (14) & 3 & 0 & $1(33)$ & \\
\hline & & $\begin{array}{l}\text { Marmosops } \\
\text { paulensis }\end{array}$ & & 6 & $1(17)$ & $1(17)$ & $\mathrm{TCl}(1)$ \\
\hline & & Marmosops sp. & & 5 & $1(20)$ & $1(20)$ & nd \\
\hline & Metachirus & $\begin{array}{l}\text { Metachirus } \\
\text { nudicaudatus }\end{array}$ & $1 / 15(7)$ & 15 & $1(8)$ & $3(23)$ & nd \\
\hline & Micoureus & $\begin{array}{l}\text { Micoureus } \\
\text { paraguayanus }\end{array}$ & $1 / 7(14)$ & 7 & $1(14)$ & 0 & TCIV (1) \\
\hline & & $\begin{array}{l}\text { Micoureus } \\
\text { demerarae }\end{array}$ & & 8 & 0 & $3(37)$ & \\
\hline & Monodelphis & $\begin{array}{l}\text { Monodelphis } \\
\text { americana }\end{array}$ & $2 / 27(7)$ & 2 & $1(50)$ & 0 & \\
\hline & & $\begin{array}{l}\text { Monodelphis } \\
\text { dimidiata }\end{array}$ & & 8 & 0 & 0 & \\
\hline & & $\begin{array}{l}\text { Monodelphis } \\
\text { domestica }\end{array}$ & & 3 & $1(33)$ & 0 & $\mathrm{TCl}(1)$ \\
\hline & & Monodelphis sp. & & 14 & 0 & 0 & \\
\hline
\end{tabular}


Table 7 Trypanosoma cruzi natural infection in free-living wild mammals from the Atlantic Forest biome: taxonomic identification of the examined mammals, results of hemocultures, indirect immunofluorescence tests (IFAT), and characterization of parasites. In the case of insufficient blood for hemocultures and serological tests, we prioritized the blood cultures (Continued)

\begin{tabular}{|c|c|c|c|c|c|c|c|}
\hline Order & Genus & Species & $\begin{array}{l}\text { No. of } \\
\text { genera }(\%)^{a}\end{array}$ & $\begin{array}{l}\text { No. of } \\
\text { specimens }\end{array}$ & $\begin{array}{l}\mathrm{HC}(+) / \\
\text { specimens tested (\%) }\end{array}$ & $\begin{array}{l}\text { IFAT(+)/ } \\
\text { specimens tested (\%) }\end{array}$ & DTU $(n)$ \\
\hline & Philander & $\begin{array}{l}\text { Philander } \\
\text { frenatus }\end{array}$ & $22 / 106(21)$ & 67 & $19(28)$ & $8(12)$ & Tcl (7); Tcll (4) \\
\hline & & $\begin{array}{l}\text { Philander } \\
\text { opossum }\end{array}$ & & 2 & 0 & 0 & \\
\hline & & Philander sp. & & 37 & $3(8)$ & $7(19)$ & $\begin{array}{l}\text { Tcl (1)//TcIV (1); } \\
\text { Tcl+T. rangeli (1) }\end{array}$ \\
\hline \multirow[t]{7}{*}{ Primates } & Callithrix & Callithrix jacchus & $2 / 4(50)$ & 1 & $1(100)$ & 0 & $\mathrm{TCl}(1)$ \\
\hline & & Callithrix geoffroy & & 2 & $1(50)$ & nd & \\
\hline & & Callithrix sp. & & 1 & 0 & 0 & \\
\hline & Cebus & Cebus apella & $1 / 1(100)$ & 1 & $1(100)$ & 0 & Tcll (1) \\
\hline & Leontopithecus & $\begin{array}{l}\text { Leontopithecus } \\
\text { chrysomelas }\end{array}$ & $91 / 374(24)$ & 87 & $39(45)$ & $48(55)$ & Tcl (1);Tcll (14) \\
\hline & & $\begin{array}{l}\text { Leontopithecus } \\
\text { chrysopygus }\end{array}$ & & 1 & $1(100)$ & 0 & \\
\hline & & $\begin{array}{l}\text { Leontopithecus } \\
\text { rosalia }\end{array}$ & & 286 & $51(18)$ & $94(33)$ & $\begin{array}{l}\text { Tcl (4); Tcll (26); } \\
\text { Tcl+Tcll (1) }\end{array}$ \\
\hline \multirow[t]{26}{*}{ Rodentia } & Abrawayaomy & Abrawayaomys sp. & 1 & 1 & 0 & 0 & \\
\hline & Akodon & Akodon cursor & 2/529 (0.4) & 7 & 0 & 0 & \\
\hline & & Akodon montensis & & 57 & 0 & 0 & \\
\hline & & Akodon paranaensis & & 7 & 0 & 0 & \\
\hline & & Akodon sp. & & 458 & $2(0.5)$ & $20(4)$ & $\mathrm{Tcl}(1)$ \\
\hline & Brucepattersonius & Brucepattersonius sp. & 24 & 24 & 0 & 0 & \\
\hline & Calomys & Calomys sp. & 4 & 4 & 0 & $1(25)$ & \\
\hline & Cavia & Cavia sp. & 2 & 2 & 0 & $1(50)$ & \\
\hline & Cerradomys & Cerradomys sp. & 1 & 1 & 0 & 0 & \\
\hline & Coendou & Coendou sp. & 1 & 1 & 0 & 0 & \\
\hline & Delomys & Delomys dorsalis & 1 & 1 & 0 & 0 & \\
\hline & Euryoryzomys & Euryoryzomys russatus & 9 & 9 & 0 & 0 & \\
\hline & Euryzygomatomys & $\begin{array}{l}\text { Euryzygomatomys } \\
\text { spinosus }\end{array}$ & 3 & 3 & 0 & 0 & \\
\hline & Galea & Galea spixii & 1 & 1 & 0 & 0 & \\
\hline & Hyleamys & Hyleamys sp. & 1 & 1 & 0 & 0 & \\
\hline & Juliomys & Juliomys pictipes & 1 & 1 & 0 & 0 & \\
\hline & Mus & Mus musculus & 16 & 15 & 0 & 0 & \\
\hline & & Mus sp. & & 1 & 0 & 0 & \\
\hline & Necromys & Necromys lasiurus & 12 & 12 & 0 & $2(16)$ & \\
\hline & Nectomys & $\begin{array}{l}\text { Nectomys } \\
\text { squamipes }\end{array}$ & 3/135 (2) & 30 & $1(3)$ & $4(13)$ & $\mathrm{TCl}(1)$ \\
\hline & & Nectomys rattus & & 6 & 0 & $1(17)$ & \\
\hline & & Nectomys sp. & & 99 & $2(2)$ & $1(1)$ & $\mathrm{Tcl}(1)$ \\
\hline & Oligoryzomys & $\begin{array}{l}\text { Oligoryzomys } \\
\text { flavescens }\end{array}$ & 479 & 1 & 0 & 0 & \\
\hline & & $\begin{array}{l}\text { Oligoryzomys } \\
\text { nigripes }\end{array}$ & & 116 & 0 & $3(3)$ & \\
\hline & & Oligoryzomys sp. & & 362 & 0 & 1 & \\
\hline & Oryzomys & Oryzomys sp. & 4 & 4 & 0 & 0 & \\
\hline
\end{tabular}


Table 7 Trypanosoma cruzi natural infection in free-living wild mammals from the Atlantic Forest biome: taxonomic identification of the examined mammals, results of hemocultures, indirect immunofluorescence tests (IFAT), and characterization of parasites. In the case of insufficient blood for hemocultures and serological tests, we prioritized the blood cultures (Continued)

\begin{tabular}{|c|c|c|c|c|c|c|c|}
\hline Order & Genus & Species & $\begin{array}{l}\text { No. of } \\
\text { genera (\%) }\end{array}$ & $\begin{array}{l}\text { No. of } \\
\text { specimens }\end{array}$ & $\begin{array}{l}\mathrm{HC}(+) / \\
\text { specimens tested (\%) }\end{array}$ & $\begin{array}{l}\text { IFAT(+)/ } \\
\text { specimens tested (\%) }\end{array}$ & DTU $(n)$ \\
\hline & \multirow[t]{2}{*}{ Oxymycterus } & Oxymycterus judex & \multirow[t]{2}{*}{32} & 14 & 0 & 0 & \\
\hline & & Oxymycterus sp. & & 18 & 0 & $3(17)$ & \\
\hline & Rattus & Rattus rattus & 35 & 35 & 0 & $9(26)$ & \\
\hline & Rhipidomys & Rhipidomys sp. & 3 & 3 & 0 & $1(33)$ & \\
\hline & Sooretamys & Sooretamys angouya & 12 & 12 & 0 & 0 & \\
\hline & Sphiggurus & Sphiggurus villosus & 1 & 1 & 0 & 0 & \\
\hline & Thaptomys & Thaptomys nigrita & 81 & 81 & 0 & 0 & \\
\hline & \multirow[t]{2}{*}{ Thrichomys } & Thrichomys apereoides & \multirow[t]{2}{*}{8} & 6 & 0 & $2(33)$ & \\
\hline & & Thrichomys sp. & & 2 & 0 & 0 & \\
\hline & \multirow[t]{3}{*}{ Trinomys } & Trinomys iheringi & \multirow[t]{3}{*}{24} & 3 & 0 & 0 & \\
\hline & & Trinomys paratus & & 10 & 0 & $2(20)$ & \\
\hline & & Trinomys sp. & & 11 & 0 & $4(36)$ & \\
\hline Total: 5 & 43 & & & 2416 & 205/2416 (8.5) & $340 / 2375$ (14) & $P<0.0001$ \\
\hline
\end{tabular}

${ }^{a}$ Number of genera with infected species/number of genera examined Abbreviations: $\mathrm{HC}(+)$, number of specimens with positive hemocultures; IFAT(+), number of specimens with positive IFAT test; DTU, Discrete Typing Units; $\mathrm{n}$, number of isolates; nd, not done

As avid insect predators [50], coatis may acquire $T$. cruzi infections via the oral route, which is recognized as highly efficient [56]. In fact, the dense fur of the majority of wild mammal species most probably acts as a barrier against the infection via the contaminative route. Nasua nasua has been described as a competent T. cruzi reservoir due to their long-lasting parasitemia demonstrated by positive hemocultures. Furthermore, $N$. nasua has been shown to be able to maintain the main genotypes of T. cruzi (TcI and TcII) in mixed or single infections (Table 4). This ability to maintain $T$. cruzi populations, together with their generalist character, suggests that the coatis may be exposed to many or all of the various transmission cycles of the parasite. Taken all together, this implies that this species may act as a hub of the T. cruzi transmission network and a bio-accumulator of $T$. cruzi subpopulations [3, 27, 30, 47]. Also of interest is that Rocha et al. [3] observed T. cruzi isolates that did not fit into any of the six recognized DTUs, suggesting that there is still much to learn about the diversity of this parasite. Table 4 shows infection rates and T. cruzi genotypes observed in N. nasua from Pantanal region.

\section{Primates: golden lion tamarins in the Atlantic Forest and Cebidae in the Amazon region}

New World primates are essentially arboreal, and some use their prehensile tail as a fifth limb. It is currently accepted that this taxon (as well as caviomorph rodents)

Table 8 Trypanosoma cruzi natural infection in free-living wild mammals of Brazilian biomes: mammalian taxa that present the highest competencies for infection as expressed by positive blood cultures

\begin{tabular}{|c|c|c|c|c|c|c|}
\hline Order & Genus & Biome & No. of specimens & $\mathrm{HC}(+) /$ specimens tested (\%) & IFAT(+)/ specimens tested (\%) & $P$-value \\
\hline \multirow[t]{6}{*}{ Didelphimorphia } & Didelphis & Amazon Forest & 64 & $24(37)$ & $45(70)$ & 0.0001 \\
\hline & Philander & & 68 & $24(35)$ & $50(73)$ & $<0.0001$ \\
\hline & Didelphis & Atlantic Forest & 410 & $77(19)$ & $111(27)$ & 0.004 \\
\hline & Philander & & 106 & $22(20)$ & $15(14)$ & 0.2776 \\
\hline & Didelphis & Caatinga & 134 & $49(36)$ & $71(53)$ & 0.0099 \\
\hline & Didelphis & Cerrado & 118 & $9(8)$ & $34(29)$ & $<0.0001$ \\
\hline \multirow[t]{3}{*}{ Primates } & Leontopithecus & Atlantic Forest & 374 & $91(24)$ & $205(55)$ & $<0.0001$ \\
\hline & Sapajus & Amazon Forest & 46 & $25(54)$ & $10(22)$ & 0.0026 \\
\hline & Alouatta & & 11 & $3(27)$ & $8(73)$ & 0.0881 \\
\hline Carnivora & Nasua & Pantanal & 230 & $76(33)$ & $77(33)$ & 0.9212 \\
\hline
\end{tabular}

Abbreviations: $\mathrm{HC}(+)$, number of specimens with positive hemocultures; IFAT(+), number of specimens with positive indirect immunofluorescence test (IFAT) 
Table 9 Trypanosoma spp. natural infection in Chiroptera from Brazilian biomes: partial results of characterization of Trypanosoma spp. isolates derived from 1218 bats collected in five Brazilian biomes Parasite molecular target (V7V8 SSU rRNA / Cytb / 18S)

\begin{tabular}{|c|c|c|c|c|c|c|}
\hline Biome & Genus & Species & $\begin{array}{l}\text { No. of } \\
\text { genera }(\%)^{a}\end{array}$ & $\begin{array}{l}\text { No. of } \\
\text { specimens }\end{array}$ & $\begin{array}{l}\mathrm{HC}(+) / \\
\text { specimens tested (\%) }\end{array}$ & $\begin{array}{l}\text { Trypanosoma spp. or } \\
\text { T. cruzi DTU }(n)\end{array}$ \\
\hline \multirow[t]{25}{*}{ Amazon Forest } & Anoura & $\begin{array}{l}\text { Anoura } \\
\text { caudifer }\end{array}$ & 1 & 2 & $1(50)$ & T. cruzi Tcl (1) \\
\hline & Artibeus & $\begin{array}{l}\text { Artibeus } \\
\text { lituratus }\end{array}$ & $127(15.7)$ & 59 & $6(10)$ & $\begin{array}{l}\text { Trypanosona sp. (1); } \\
\text { T. cruzi TcIV (2); T. cruzi Tcl (3) }\end{array}$ \\
\hline & & $\begin{array}{l}\text { Artibeus cf. } \\
\text { fimbriatus }\end{array}$ & & 1 & $1(100)$ & T. cruzi Tcl (1) \\
\hline & & $\begin{array}{l}\text { Artibeus } \\
\text { obscurus }\end{array}$ & & 5 & $1(20)$ & Trypanosona sp. (1) \\
\hline & & $\begin{array}{l}\text { Artibeus } \\
\text { planirostris }\end{array}$ & & 62 & $12(19)$ & $\begin{array}{l}\text { Trypanosona sp. (4); T. c. marinkellei (2); } \\
\text { T. cruzi Tcl (4); T. rangeli (sub-população A) } \\
\text { (1); T. dionisii (1) }\end{array}$ \\
\hline & Carollia & $\begin{array}{l}\text { Carollia } \\
\text { perspicillata }\end{array}$ & $131(25.1)$ & 118 & $29(24)$ & $\begin{array}{l}\text { T. cruzi Tcl (20); T. dionisii (3); T. rangeli } \\
\text { (subpopulation A) (1); Trypanosona sp. } \\
\text { (4); Trypanosoma sp. + T. cruzi Tcl (1) }\end{array}$ \\
\hline & & $\begin{array}{l}\text { Carollia cf. } \\
\text { beikeith }\end{array}$ & & 1 & $1(100)$ & T. cruzi Tcl (1) \\
\hline & & $\begin{array}{l}\text { Carollia } \\
\text { brevicauda }\end{array}$ & & 12 & $3(25)$ & T. cruzi Tcl (3) \\
\hline & Chiroderma & $\begin{array}{l}\text { Chiroderma } \\
\text { villosum }\end{array}$ & 3 & 3 & 0 & \\
\hline & Dermanura & $\begin{array}{l}\text { Dermanura } \\
\text { cinereus }\end{array}$ & $13(7.0)$ & 13 & $1(7)$ & T. cruzi Tcl (1) \\
\hline & Desmodus & $\begin{array}{l}\text { Desmodus } \\
\text { rotundus }\end{array}$ & 2 & 2 & 0 & \\
\hline & Diaemus & Diaemus youngi & 1 & 1 & 0 & \\
\hline & Eptesicus & $\begin{array}{l}\text { Eptesicus } \\
\text { brasiliensis }\end{array}$ & $3(33.3)$ & 3 & $1(33)$ & Trypanosona sp. (1) \\
\hline & Glossophaga & $\begin{array}{l}\text { Glossophaga } \\
\text { soricina }\end{array}$ & $11(18.2)$ & 11 & $2(18)$ & T. cruzi TcIV (1); T. cruzi Tcl (1) \\
\hline & Lasiurus & $\begin{array}{l}\text { Lasiurus } \\
\text { blossevillii }\end{array}$ & $2(50.0)$ & 2 & $1(50)$ & T. cruzi Tcl (1) \\
\hline & Lonchophylla & $\begin{array}{l}\text { Lonchophylla } \\
\text { thomasi }\end{array}$ & $5(20.0)$ & 5 & $1(20)$ & T. cruzi Tcl (1) \\
\hline & Lophostoma & $\begin{array}{l}\text { Lophostoma } \\
\text { silvicolum }\end{array}$ & $3(66.7)$ & 3 & $2(66)$ & T. c. marinkellei (2) \\
\hline & Mesophylla & $\begin{array}{l}\text { Mesophylla } \\
\text { macconelli }\end{array}$ & 2 & 2 & 0 & \\
\hline & Micronycteris & $\begin{array}{l}\text { Micronycteris } \\
\text { megalotis }\end{array}$ & 1 & 1 & 0 & \\
\hline & Molossus & $\begin{array}{l}\text { Molossus } \\
\text { aff. rufus }\end{array}$ & 3 & 3 & 0 & \\
\hline & Noctilio & $\begin{array}{l}\text { Noctilio } \\
\text { albiventris }\end{array}$ & 1 & 1 & 0 & \\
\hline & Mimom & $\begin{array}{l}\text { Mimom } \\
\text { crenulatum }\end{array}$ & & 1 & 0 & \\
\hline & Phyllostomus & $\begin{array}{l}\text { Phyllostomus } \\
\text { discolor }\end{array}$ & $32(53.1)$ & 7 & $6(85)$ & $\begin{array}{l}\text { T. cruzi Tcl (2); T. c. marinkellei } \\
\text { (2); Trypanosona sp. (2) }\end{array}$ \\
\hline & & $\begin{array}{l}\text { Phyllostomus } \\
\text { elongatus }\end{array}$ & & 12 & $2(16)$ & Trypanosona sp. (1); T. c. marinkellei (1) \\
\hline & & $\begin{array}{l}\text { Phyllostomus } \\
\text { hastatus }\end{array}$ & & 13 & $9(69)$ & $\begin{array}{l}\text { Trypanosona sp. (3); T. c. marinkellei (5); } \\
\text { T. cruzi TcIV + T. c. marinkellei (1) }\end{array}$ \\
\hline
\end{tabular}


Table 9 Trypanosoma spp. natural infection in Chiroptera from Brazilian biomes: partial results of characterization of Trypanosoma spp. isolates derived from 1218 bats collected in five Brazilian biomes Parasite molecular target (V7V8 SSU rRNA / Cytb / 18S) (Continued)

\begin{tabular}{|c|c|c|c|c|c|c|}
\hline Biome & Genus & Species & $\begin{array}{l}\text { No. of } \\
\text { genera (\%) }\end{array}$ & $\begin{array}{l}\text { No. of } \\
\text { specimens }\end{array}$ & $\begin{array}{l}\mathrm{HC}(+) / \\
\text { specimens tested (\%) }\end{array}$ & $\begin{array}{l}\text { Trypanosoma spp. or } \\
\text { T. cruzi DTU }(n)\end{array}$ \\
\hline & \multirow[t]{2}{*}{ Plathyrhinus } & Plathyrhinus infuscus & \multirow[t]{2}{*}{$3(33.3)$} & 2 & $1(50)$ & \multirow[t]{5}{*}{ T. cruzi Tcl (1) } \\
\hline & & $\begin{array}{l}\text { Plathyrhinus } \\
\text { incarum }\end{array}$ & & 1 & 0 & \\
\hline & \multirow[t]{2}{*}{ Rhynophylla } & $\begin{array}{l}\text { Rhynophylla } \\
\text { pumilio }\end{array}$ & \multirow[t]{2}{*}{9} & 5 & 0 & \\
\hline & & $\begin{array}{l}\text { Rhinophylla } \\
\text { fischerae }\end{array}$ & & 4 & 0 & \\
\hline & Saccopteryx & $\begin{array}{l}\text { Saccopteryx } \\
\text { leptura }\end{array}$ & 1 & 1 & 0 & \\
\hline & \multirow[t]{2}{*}{ Sturnira } & Sturnira lilium & \multirow[t]{2}{*}{$6(33.3)$} & 2 & $1(50)$ & Trypanosona sp. (1) \\
\hline & & Sturnira tildae & & 4 & $1(25)$ & T. dionisii (1) \\
\hline & Tonatia & $\begin{array}{l}\text { Tonatia } \\
\text { saurophila }\end{array}$ & $3(33.3)$ & 3 & $1(33)$ & T. cruzi Tcl (1) \\
\hline & Trachops & $\begin{array}{l}\text { Trachops } \\
\text { cirrhosus }\end{array}$ & $3(100)$ & 3 & $3(100)$ & T. cruzi Tcl (2); T. dionisii (1) \\
\hline & Uroderma & $\begin{array}{l}\text { Uroderma } \\
\text { bilobatum }\end{array}$ & $13(7)$ & 13 & $1(7)$ & T. cruzi Tcl (1) \\
\hline & Vampyrum & $\begin{array}{l}\text { Vampyrum } \\
\text { spectrum }\end{array}$ & 1 & 1 & 0 & \\
\hline & Vampyrodes & $\begin{array}{l}\text { Vampyrodes } \\
\text { caraccioli }\end{array}$ & 1 & 1 & 0 & \\
\hline & Vampyressa sp. & Vampyressa sp. & $1(100)$ & 1 & $1(100)$ & T. cruzi Tcl (1) \\
\hline \multirow[t]{14}{*}{ Atlantic Forest } & Ametrida & $\begin{array}{l}\text { Ametrida } \\
\text { centurio }\end{array}$ & 1 & 1 & 0 & \\
\hline & \multirow[t]{2}{*}{ Anoura } & Anoura caudifer & \multirow[t]{2}{*}{$21(14.2)$} & 11 & $1(9)$ & Trypanosona sp. (1) \\
\hline & & Anoura geoffroyi & & 10 & $2(20)$ & T. dionisii (2) \\
\hline & \multirow[t]{5}{*}{ Artibeus } & Artibeus cinereus & \multirow[t]{5}{*}{$305(1.3)$} & 21 & 0 & \\
\hline & & $\begin{array}{l}\text { Artibeus } \\
\text { fimbriatus }\end{array}$ & & 6 & $1(16)$ & T. cruzi Tcl (1) \\
\hline & & $\begin{array}{l}\text { Artibeus } \\
\text { lituratus }\end{array}$ & & 81 & $2(2)$ & $\begin{array}{l}\text { T. cruzi TcIIII (1); } \\
\text { T. cruzi TcIIIN (1) }\end{array}$ \\
\hline & & $\begin{array}{l}\text { Artibeus } \\
\text { obscurus }\end{array}$ & & 4 & 0 & \\
\hline & & $\begin{array}{l}\text { Artibeus } \\
\text { planirostris }\end{array}$ & & 193 & $1(0.5)$ & T. cruzi Tcl (1) \\
\hline & Carollia & $\begin{array}{l}\text { Carollia } \\
\text { perspicillata }\end{array}$ & $133(18.0)$ & 133 & $24(18)$ & $\begin{array}{l}\text { T. cruzi TcIV (1); T. dionisii (20); } \\
\text { Trypanosoma sp. (1); } \\
\text { Trypanosoma rangeli D (1); } \\
\text { Trypanosoma rangeli B (1) }\end{array}$ \\
\hline & Chrotopterus & $\begin{array}{l}\text { Chrotopterus } \\
\text { auritus }\end{array}$ & 1 & 1 & 0 & \\
\hline & Dermanura & $\begin{array}{l}\text { Dermanura } \\
\text { cinerea }\end{array}$ & 22 & 22 & 0 & \\
\hline & Desmodus & $\begin{array}{l}\text { Desmodus } \\
\text { rotundus }\end{array}$ & $30(16.7)$ & 30 & $5(16)$ & $\begin{array}{l}\text { T. cruzi TcllIN (1); T. cruzi Tcl (1); } \\
\text { Trypanosoma sp. (1); T. dionisii (2) }\end{array}$ \\
\hline & Lonchorrina & $\begin{array}{l}\text { Lonchorrina } \\
\text { aurita }\end{array}$ & 1 & 1 & 0 & \\
\hline & Glossophaga & $\begin{array}{l}\text { Glossophaga } \\
\text { soricina }\end{array}$ & $23(4.3)$ & 23 & $1(4)$ & T. dionisii (1) \\
\hline
\end{tabular}


Table 9 Trypanosoma spp. natural infection in Chiroptera from Brazilian biomes: partial results of characterization of Trypanosoma spp. isolates derived from 1218 bats collected in five Brazilian biomes Parasite molecular target (V7V8 SSU rRNA / Cytb / 18S) (Continued)

\begin{tabular}{|c|c|c|c|c|c|c|}
\hline Biome & Genus & Species & $\begin{array}{l}\text { No. of } \\
\text { genera }(\%)^{a}\end{array}$ & $\begin{array}{l}\text { No. of } \\
\text { specimens }\end{array}$ & $\begin{array}{l}\mathrm{HC}(+) / \\
\text { specimens tested (\%) }\end{array}$ & $\begin{array}{l}\text { Trypanosoma spp. or } \\
\text { T. cruzi DTU }(n)\end{array}$ \\
\hline & Glyphonycteris & Glyphonycteris sylvestris & 1 & 1 & 0 & \\
\hline & Lophostoma & Lophostoma silvicolum & 1 & 1 & 0 & \\
\hline & Micronycteris & Micronycteris microtis & $1 / 3(33.3)$ & 2 & 0 & \\
\hline & & Micronycteris minuta & & 1 & $1(100)$ & T. cruzi Tcl/III (1) \\
\hline & Mimon & Mimon bennettii & 2 & 2 & 0 & \\
\hline & Myotis & Myotis nigricans & $10(40.0)$ & 10 & $4(40)$ & T. dionisii (3); T. cruzi TcIIIN (1) \\
\hline & Phyllostomus & Phyllostomus discolor & $23(13.0)$ & 11 & $3(27)$ & T. cruzi Tcl (1); T. c. marinkellei (2) \\
\hline & & Phyllostomus hastatus & & 12 & 0 & \\
\hline & Platyrrhinus & Platyrrhinus lineatus & 9 & 9 & 0 & \\
\hline & & Platyrrhinus recifinus & & 1 & 0 & \\
\hline & Rinophyla & Rinophyla pumilio & 5 & 5 & 0 & \\
\hline & & Rinophyla sp. & $1(5.9)$ & 1 & 0 & \\
\hline & Sturnira & Sturnira lilium & $41(12.1)$ & 40 & $5(12)$ & T. dionisii (4); Trypanosona sp. (1) \\
\hline & & Sturnira tildae & & 1 & 0 & \\
\hline & Tonatia & Tonatia bidens & $3(33.3)$ & 3 & $1(33)$ & T. dionisii (1) \\
\hline & Tracops & Tracops cirrhosus & $1(100)$ & 1 & $1(100)$ & Trypanosoma sp. (1) \\
\hline & Vampyressa & Vampyressa pusilla & 1 & 1 & 0 & \\
\hline \multirow[t]{2}{*}{ Caatinga } & Phyllostomus & Phyllostomus sp. & 2 & 2 & 0 & \\
\hline & Molossus & Molossus sp. & 3 & 3 & 0 & \\
\hline \multirow[t]{16}{*}{ Cerrado } & Artibeus & Artibeus lituratus & $49(10.2)$ & 11 & $1(9)$ & Trypanosoma sp. (1) \\
\hline & & Artibeus planirostris & & 37 & $4(10)$ & Trypanosoma sp. (3); T. c. marinkellei (1) \\
\hline & & Artibeusaff. Obscurus & & 1 & 0 & \\
\hline & Carollia & Carollia perspicillata & $24(4.0)$ & 24 & $1(4)$ & Trypanosoma sp. (1) \\
\hline & Desmodus & Desmodus rotundus & $4(25.0)$ & 4 & $1(25)$ & Trypanosoma sp. (1) \\
\hline & Glossophaga & Glossophaga soricina & $7(14.0)$ & 7 & $1(14)$ & Trypanosoma sp. (1) \\
\hline & Molossops & Molossops sp. & 2 & 2 & 0 & \\
\hline & Phyllostomus & Phyllostomus albicola & $12(83.3)$ & 1 & $1(100)$ & Trypanosoma sp. (1) \\
\hline & & Phyllostomus discolor & & 1 & 1 & Trypanosoma sp. (1) \\
\hline & & Phyllostomus hastatus & & 11 & $9(81)$ & Trypanosoma sp. (4) \\
\hline & Platyrhinus & Platyrhinus lineatus & 7 & 7 & 0 & \\
\hline & Sturnira & Sturnira lilium & $4(25.0)$ & 4 & $1(25)$ & T. dionisii (1) \\
\hline & Eptesicus & Eptesicus brasiliensis & 3 & 3 & 0 & \\
\hline & Eumops & Eumops sp. & 6 & 6 & 0 & \\
\hline & Myotis & Myotis nigricans & 1 & 1 & 0 & \\
\hline & Rhynchonycteris & Rhynchonycteris naso & $1(5.9)$ & 1 & 0 & \\
\hline \multirow[t]{7}{*}{ Pantanal } & Artibeus & Artibeus jamaicensis & $16(18.7)$ & 1 & $1(100)$ & Trypanosoma sp. (1) \\
\hline & & Artibeus planirostris & & 15 & $2(13)$ & Trypanosoma sp. (1); T. c. marinkellei (1) \\
\hline & Carollia & Carollia perspicillata & $4(5.9)$ & 4 & 0 & \\
\hline & Chrotopterus & Chrotopterus autirus & $1(5.9)$ & 1 & 0 & \\
\hline & Desmodus & Desmodus rotundus & $18(16.6)$ & 18 & $3(16)$ & T. c. marinkellei (1); Trypanosoma sp. (2) \\
\hline & Glossophaga & Glossophaga soricina & 3 & 3 & 0 & \\
\hline & Lophostoma & Lophostoma silvicolum & 5 & 5 & 0 & \\
\hline
\end{tabular}


Table 9 Trypanosoma spp. natural infection in Chiroptera from Brazilian biomes: partial results of characterization of Trypanosoma spp. isolates derived from 1218 bats collected in five Brazilian biomes Parasite molecular target (V7V8 SSU rRNA / Cytb / 18S) (Continued)

\begin{tabular}{|c|c|c|c|c|c|c|}
\hline Biome & Genus & Species & $\begin{array}{l}\text { No. of } \\
\text { genera (\%) }\end{array}$ & $\begin{array}{l}\text { No. of } \\
\text { specimens }\end{array}$ & $\begin{array}{l}\mathrm{HC}(+) / \\
\text { specimens tested (\%) }\end{array}$ & $\begin{array}{l}\text { Trypanosoma spp. or } \\
\text { T. cruzi DTU }(n)\end{array}$ \\
\hline & Molossops & Molossops temminckii & 1 & 1 & 0 & \\
\hline & Molossus & Molossus molossus & 2 & 2 & 0 & \\
\hline & Myotis & Myotis migricans & 1 & 1 & 0 & \\
\hline & Noctilio & Noctilio albiventris & 2 & 2 & 0 & \\
\hline & Platyrrhinus & Platyrrhinus lineatus & 9 & 9 & 0 & \\
\hline & Phyllostomus & Phyllostomus hastatus & $5(60.0)$ & 5 & $3(60)$ & Trypanosoma sp. (1); T. c. marinkellei (2) \\
\hline & Sturnira & Sturnira lilium & $3(33.3)$ & 3 & $1(33)$ & T. dionisii (1) \\
\hline Total & 76 & 94 & $1218(5.9)$ & 1219 & $168(14)$ & \\
\hline
\end{tabular}

${ }^{a}$ Number of genera with infected species/number of genera examined

Abbreviations: $\mathrm{HC}(+)$, number of specimens with positive hemocultures; DTU, Discrete Typing Units; $n$, number of isolates

have entered the Americas coming from Africa after crossing the Atlantic Ocean 35 MYBP [57, 58]. Very probably, they were included in the $T$. cruzi transmission cycle maintained at that time by the autochthonous mammalian fauna once they arrived the New World.

Primates of distinct genera and species may act as important reservoirs of T. cruzi (Table 8) with positive hemocultures in 119 of 431 (27.6\%) primates examined. These primates were infected with TcI and TcII (Tables 2 and 7). Tamarins (Leontopithecus rosalia and L. chrysomelas) were found infected with T. cruzi in the Atlantic Costal Forest in both the southeast and the northeast regions, mainly with TcII, but also with TcI (Table 7).

Tamarins are diurnal primates that live in social groups of up to ten individuals. Leontopithecus rosalia, the golden lion tamarin (GLT), is an elegant and delicate primate; the adult weighs between 360 and $710 \mathrm{~g}$, and $60 \mathrm{~g}$ is considered normal for a GLT puppy. They are endemic to the Atlantic Forest and are in serious danger of extinction. Tamarins can live up to 15 years and are essentially arboreal.

A ten-year follow-up of T. cruzi infection revealed that $L$. rosalia is able to maintain a stable and long-lasting $T$. cruzi TcII transmission focus. It is interesting to note that in the studied area, only L. rosalia showed infection with this DTU: the other mammals were infected only with TcI. Leontopithecus rosalia infection with TcI was also observed in the area that is made up of a complex of forest fragments designed for tamarin conservation. Still in the Atlantic Forest, but in the northeast of the country, another species of tamarin (L. chrysomelas) also showed high rates of infection with $T$. cruzi TcII [25]. Such a stable transmission cycle of T. cruzi DTU TcII is not frequently found in the wild environment. What is seen in nature is that TcII infects numerous species of wild mammals distributed in all biomes but at low rates of infection. Trypanosoma cruzi DTU TcI is strongly predominant among free-living wild mammals [2]. An interesting aspect shown by the study of $T$. cruzi infection in tamarins is that even in a small area (5500 ha), such as the forest fragment where these primates were studied, the T. cruzi infection distribution was aggregated [25].

The congenital infection of $L$. rosalia is probably not very frequent because $T$. cruzi infection was not observed in juveniles [25]. Possible sites of infection are the hollows of trees that serve as a night shelter for these animals. Each hollow is shared by a social group in a rotation system of the hollows used. Inside a hollow, animals sleep tightly curled and the younger animals are at the centre. A hollow tree might be a suitable habitat for triatomine bugs in that there is an abundant food supply offered by the tamarins. These hollows are high, deep in the trunks and feature a very narrow entrance. The oral route by ingestion of infected triatomine must also be an important route of infection in tamarins, even if triatomine bugs are not very attractive insects because of their scent glands. The simple act of chewing the insect may result in infection, even if the insect is later ejected. Studies on the health of GLTs infected with T. cruzi based on electrocardiograms, blood tests and electrophoretograms showed that GLTs appear to support the parasitization by T. cruzi without major damage [59].

High rates of $T$. cruzi infection with high parasitemia were also observed in Sapajus libidinosus (Cebidae) in the Amazon (Tables 2 and 8). This species is the only New World monkey that uses tools in the natural environment to break nuts. Sapajus spp. are strictly diurnal, display arboreal habits and spend most of their time foraging and moving through their life area ( $\sim 300 \mathrm{ha})$ [60]. They are extremely social mammals that live in groups of up to 50 individuals, led by a larger, older male. They are also cooperative in raising young and finding food. Cebidas are long-living animals and sexual maturity occurs earlier in females (4-5 years) than in males (8-10 years). These 
primates do not constitute stable pairs and males and females mate with multiple individuals, making determination of paternity difficult $[61,62]$.

Cebids are difficult subjects for research and we did not have chance to conduct a long-term study. Concerning $T$. cruzi infection, S. libidinosus presented TcI in single and mixed infections with $T$. rangeli. Single infections with $T$. rangeli have been also observed (Table 2 ).

All species of Sapajus are omnivorous, but their main diet consists of fruits and insects, in addition to small vertebrates including mammals, which means that the oral route must be important route of infection with $T$. cruzi in this primate group. Sapajus spp. are arboreal primates and trees are selected in part for food availability. They frequently use palm trees as places to sleep which also provide shelter to triatomine bugs; consequently, infection via the contaminative route during the night is also possible.

\section{Chiroptera}

Table 9 and Fig. 1 show the great diversity of Trypanosoma spp. infecting bats and that T. cruzi was the most abundant species of Trypanosoma (37\%). Moreover, the richness of Trypanosoma spp. infecting this mammalian taxon is much higher than observed in any other mammalian host. The majority of positive hemocultures of bats revealed the infection by other Trypanosoma spp. and not $T$. cruzi. These findings show that bats' role as T. cruzi reservoirs was probably often overestimated at a time when there was still no easy access to sequencing tools. The use of even more sensitive and high-performance tools like NGS would certainly demonstrate even greater diversity of genotypes and species in single and mixed infections in bats. In addition to bats, marsupials have also been found infected with numerous species of Trypanosoma including T. dionisii, a species considered to be an exclusive parasite

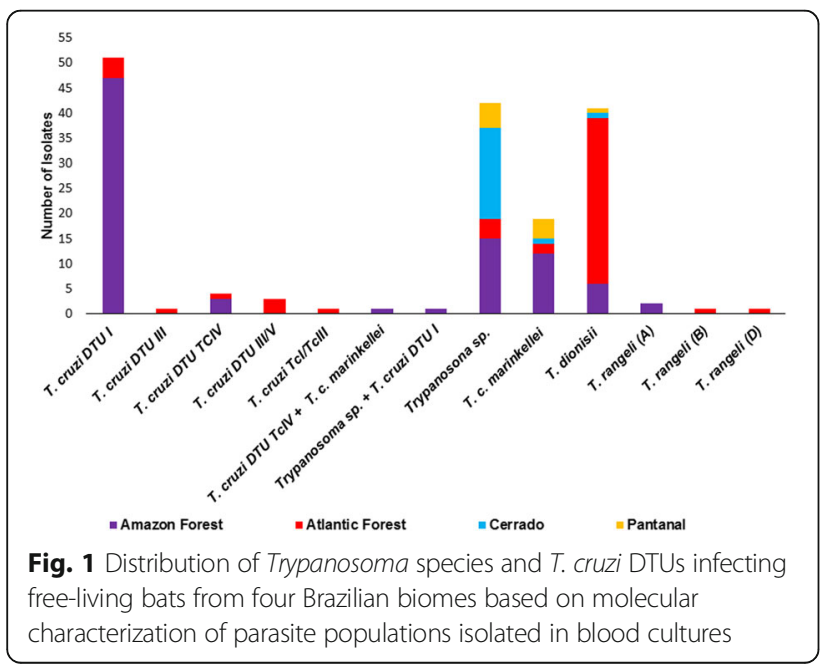

of bats until recently [44]. An important question concerns the result of such mixed infections in hosts: what are the consequences in the outcome in such mixed infections?

Bats may be considered as Trypanosoma spp. bio-accumulator hosts. There are plenty of recent descriptions of new species and still undescribed taxonomic units of Trypanosoma spp. infecting chiropterans all over the world. Chiropterans' longevity and ability to fly, as well as their capacity in maintaining $T$. cruzi DTUs and other representatives of the $T$. cruzi clade, imply in that these mammals may act as important dispersers of these flagellates. Molyneux [63], and more recently Hamilton et al. [64] proposed bats as the ancestral hosts of the $T$. cruzi clade and that terrestrial mammals became infected with $T$. cruzi as a consequence of several spillover events of the bats trypanosomes. They termed this evolutive path as "the bat seeding hypothesis". This hypothesis is currently universally accepted based on the description of trypanosomes of the T. cruzi clade infecting African bat species in contrast to the low diversity of $T$. cruzi clade species other than T. cruzi infecting the American terrestrial mammals.

During the last two decades, we examined a total of 1219 bat specimens distributed in 76 genera and 94 species of five Brazilian biomes (Table 9). High infectivity potential for Trypanosoma spp., as demonstrated by positive hemocultures, was observed in $14 \%$ of these mammals. From these, only $5 \%$ were infected with $T$. cruzi, in single or mixed infections. The remaining $9 \%$ were infected with other Trypanosoma species such as T. c. marinkellei, T. dionisii and T. rangeli (Fig. 1).

The highest rates of Trypanosoma spp. infections in bats were observed in the Amazon region (22.6\% of positive hemocultures), followed by the Cerrado biome (Table 9). As expected, a higher diversity of bats and Trypanosoma spp. species were observed in pristine forest areas in comparison to already altered forest patches. In this sense, a higher variety of bat species was observed in the Amazon in comparison to the Atlantic Forest. This issue is especially striking considering that in the Atlantic Forest the number of examined individuals was almost double that of Amazon (Table 9). Among the infected bats, 62 specimens displayed single or mixed T. cruzi DTU infections and the majority of the chiropterans were infected with TcI, but other T. cruzi DTUs also may infect bats, demonstrating that these animals are rather resilient to T. cruzi genotypes. We did not find $T$. cruzi TcII infecting Chiroptera, and these data raise doubts on what was previously known about bat Trypanosoma spp. infections and forces us to rethink the subject.

Of the bat species, members of the genera Artibeus, Carollia and Phillostomus (Phyllostomidae) exhibited the highest rates of infection with the different 
Trypanosoma species. These three genera include generalist species that feed on fruits, but also pollen and insects. Bats are important seed dispersers and probably become infected with $T$. cruzi through the contaminative and oral routes, the latter by ingestion of infected triatomine bugs and mice, as already demonstrated experimentally [65].

Next generation sequencing (NGS) demonstrated to be a promising tool to answer questions concerning Trypanosoma specificity, ecology and phylogeny. The possibility of detecting trypanosomatids that are not cultivable in axenic media, as well as the possibility of bypassing the selective forces inherent to isolation methods, are highly informative. Dario et al. [66] conducted a study by metabarcoding DNA samples extracted from blood samples of 34 bats of 13 species captured in Atlantic Forest fragments of Espírito Santo state (southeast region of Brazil). The resulting amplicon sequences could be clustered in 14 operational taxonomic units (OTUs). Five OTUs were identified as Trypanosoma cruzi TcI, T. cruzi TcIII/V, T. cruzi marinkellei, $T$. rangeli and $T$. dionisii, very common trypanosomatid species in Neotropical bats. However, seven clusters demonstrated to be novel genotypes related to the Neotropical bat genotypes. One OTU was identified as a reptile trypanosome and, surprisingly, another OTU was identified as Bodo saltans, a free-living Kinetoplastea.

The majority of the bat blood samples demonstrated mixed Trypanosoma spp. infections and also mixed OTUs infections by up to eight OTUs. The massive rates of mixed infections are certainly not exceptional in nature and deserve further studies as to evaluate their influence on the course of infection. Actually, these mixed infections cannot be overlooked.

\section{Conclusions}

The set of observations presented here is the most complete and comprehensive study on reservoirs and wild hosts of Trypanosoma cruzi. The 20 years of data collection and analyses show that there is no association of Trypanosoma cruzi DTU with mammalian host species in their habitat or the biome of their occurrence. In addition, it was possible to conclude that $T$. cruzi is transmitted and remains in the wild even if most of the individuals of the wild mammalian species infected have low parasitemias. Mixed Trypanosoma cruzi DTUs and Trypanosoma spp. are very common in the wild, and chiropterans and marsupials are the mammals that present the highest diversity of genotypes and infection rates of $T$. cruzi and other species of the genus Trypanosoma spp.

\section{Abbreviations}

Cl: confidence interval; $d f$. degrees of freedom; DTU: Discrete Typing Unit; GLT: Golden Lion Tamarin; HC: Hemoculture; IFAT: Immunofluorescent AssayTests; Labtrip: Laboratório de Biologia de Tripanosomatídeos, IOC/
Fiocruz; LIT: liver infusion tryptose; MYBP: million years before present; NGS: next generation sequencing; NNN: Novy-McNeal-Nicolle medium; OTU: Operational Taxonomic Unit; RFLP: restriction fragment length polymorphism; SOP: standard operating procedures

\section{Acknowledgments}

The authors thank Carlos Ardé and Marcos Antônio dos Santos Lima for technical support. We offer special thanks to Dr Paulo Sérgio D'Andrea for his technical support in data collection and to Dr Vera Bongertz for many helpful comments on the English version of the manuscript. All isolates in the present study originated from Trypanosoma Collection of Wild, Domestic Mammals and Vectors - Instituto Oswaldo Cruz Foundation (COLTRYP/IOC-FIOCRUZ). We offer thanks to the Program of Technological Development and Inputs for Health / Instituto Oswaldo Cruz Foundation (PDTIS/FIOCRUZ) sequencing platform for sequencing our samples. We also offer thanks to all workers from the Open Data Plan / Chico Mendes Institute for Biodiversity Conservation PDA/ICMBIO) office, to the Golden Lion Tamarin Conservation Program, Pró-carnívoros Institute, Wildlife

Conservation Society OWOH, the National Research Center for the Conservation of Predators (CENAP/ICMBIO) and the Pantanal Giant Armadillo Project.

\section{Funding}

This study was funded by the Instuto Oswaldo Cruz (IOC/Fiocruz), the European Union Seventh Framework Program Grant 223034 ChagasEpiNet, Fundação Carlos Chagas Filho de Amparo a Pesquisa do Rio de Janeiro (FAPERJ) and Conselho Nacional de Desenvolvimento Científico e Tecnológico (CNPq). The funders had no role in study design, data collection and analysis, decision to publish, or preparation of the manuscript.

\section{Authors' contributions}

AMJ conceived and designed the experiments. AMJ, ALRR and SCCX performed the fieldwork. SCCX performed and analyzed the serological characterization. AMJ and ALRR wrote the manuscript. All authors read and approved the final manuscript.

\section{Ethics approval and consent to participate}

The capture of small wild mammals was licensed by the Sistema de Autorização e Informação em Biodiversidade - SISBIO of the Instituto Brasileiro do Meio Ambiente e dos Recursos Naturais Renováveis (IBAMA), permanent license number 3365-1. Blood sample collection and euthanasia were performed and supervised by the Federal Counsel of Medical Veterinary under resolution number 1.000 approved on May 11th, 2012, according to the Ethical Committee for Animal Use of the Oswaldo Cruz Foundation (P0007-99, P0179-03; P0292/06; L0015-07; LW-81/12).

\section{Consent for publication}

Not applicable.

\section{Competing interests}

The authors declare that they have no competing interests.

\section{Publisher's Note}

Springer Nature remains neutral with regard to jurisdictional claims in published maps and institutional affiliations.

Received: 4 April 2018 Accepted: 17 August 2018

Published online: 06 September 2018

\section{References}

1. Coura JR, Viñas PA, Junqueira AC. Ecoepidemiology, short history and control of Chagas disease in the endemic countries and the new challenge for non-endemic countries. Mem Inst Oswaldo Cruz. 2014;109:856-62.

2. Jansen AM, Xavier SC, Roque AL. The multiple and complex and changeable scenarios of the Trypanosoma cruzi transmission cycle in the sylvatic environment. Acta Trop. 2015;151:1-15.

3. Rocha FL, Roque AL, de Lima JS, Cheida CC, Lemos FG, de Azevedo FC, et al. Trypanosoma cruzi infection in Neotropical wild carnivores (Mammalia: Carnivora): at the top of the T. cruzi transmission chain. PLoS One. 2013;8: e67463.

4. Deane MP, Lenzi HL, Jansen AM. Trypanosoma cruzi: vertebrate and invertebrate cycles in the same mammal host, the opossum Didelphis marsupialis. Mem Inst Oswaldo Cruz. 1984;79:513-5. 
5. Schofield C. Trypanosoma cruzi - the vector-parasite paradox. Mem Inst Oswaldo Cruz. 2000;95:535-44.

6. Tomasini N. Introgression of the kinetoplast DNA: an unusual evolutionary journey in Trypanosoma cruzi. Curr Genomics. 2018;19:133-9.

7. Guhl F, Auderheide A, Ramírez JD. From ancient to contemporary molecular eco-epidemiology of Chagas disease in the Americas. Int J Parasitol. 2014; 44:605-12.

8. Ramírez JD, Hernández C, Montilla M, Zambrano P, Flórez AC, Parra E, et al. First report of human Trypanosoma cruzi infection attributed to TcBat genotype. Zoonoses Public Health. 2014;61:477-9.

9. Keesing F, Hersh MH, Tibbetts M, McHenry DJ, Duerr S, Brunner J, et al. Reservoir competence of vertebrate hosts for Anaplasma phagocytophilum. Emerg Infect Dis. 2012;18:2013-6.

10. Huang ZYX, de Boer WF, van Langevelde F, Olson V, Blackburn TM, Prins HHT. Species' life-history traits explain interspecific variation in reservoir competence: a possible mechanism uUnderlying the dilution effect. PLoS One. 2013;8:e54341.

11. Ashford RW. What it takes to be a reservoir host. Belg J Zool. 1997;127:85-90.

12. Brunner JL, LoGiudice K, Ostfeld RS. Estimating reservoir competence of Borrelia burgdorferi hosts: prevalence and infectivity, sensitivity, and specificity. J Med Entomol. 2008;45:139-47.

13. Roque AL, D'Andrea PS, de Andrade GB, Jansen AM. Trypanosoma cruzi: distinct patterns of infection in the sibling caviomorph rodent species Thrichomys apereoides laurentius and Thrichomys pachyurus (Rodentia, Echimyidae). Exp Parasitol. 2005;111:37-46.

14. Herrera L, D'Andrea PS, Xavier SC, Mangia RH, Fernandes O, Jansen AM. Trypanosoma cruzi infection in wild mammals of the National Park 'Serra da Capivara' and its surroundings (Piaui, Brazil), an area endemic for Chagas disease. Trans R Soc Trop Med Hyg. 2005;99:379-88.

15. Rademaker V, Herrera HM, Raffel TR, D'Andrea PS, Freitas TP, Abreu UG, et al. What is the role of small rodents in the transmission cycle of Trypanosoma cruzi and Trypanosoma evansi (Kinetoplastida Trypanosomatidae)? A study case in the Brazilian Pantanal. Acta Trop. 2009;111:102-7.

16. Camargo ME. Fluorescent antibody test for the serodiagnoses of American trypanosomiasis: technical modification employing preserved culture forms of Trypanosoma cruzi in a slide test. Rev Inst Med Trop São Paulo. 1966;8:227-34.

17. Noyes HA, Stevens JR, Teixeira M, Phelan J, Holz P. A nested PCR for the ssrRNA gene detects Trypanosoma binneyi in the platypus and Trypanosoma sp. in wombats and kangaroos in Australia. Int J Parasitol. 1999;29:331-9.

18. Dario MA, Rodrigues MS, Barros JH, Xavier SC, D'Andrea PS, Roque AL, et al. Ecological scenario and Trypanosoma cruzi DTU characterization of a fatal acute Chagas disease case transmitted orally (Espírito Santo State, Brazil). Parasit Vectors. 2016;9:477.

19. Xavier SC, Roque AL, Bilac D, de Araújo VA, da Costa Neto SF, Lorosa ES, et al. Distantiae transmission of Trypanosoma cruzi: a new epidemiological feature of acute Chagas disease in Brazil. PLoS Negl Trop Dis. 2014;8:e2878.

20. Lima V dos S, Xavier SC, Maldonado IF, Roque AL, Vicente AC, Jansen AM. Expanding the knowledge of the geographic distribution of Trypanosoma cruzi Tcll and TcV/TcVl genotypes in the Brazilian Amazon. PLoS One. 2014;9: e116137.

21. Rocha FL, Roque AL, Arrais RC, Santos JP, Lima Vdos S, Xavier SC, et al. Trypanosoma cruzi TCl and TCll transmission among wild carnivores, small mammals and dogs in a conservation unit and surrounding areas, Brazil. Parasitology. 2013;140:160-70.

22. Barros JHS, Xavier SCC, Bilac D, Lima VS, Dario MA, Jansen AM. Identification of novel mammalian hosts and Brazilian biome geographic distribution of Trypanosoma cruzi TcIll and TcIV. Acta Trop. 2017;172:173-9.

23. Lisboa CV, Mangia RH, Luz SL, Kluczkovski A, Ferreira LF, Ribeiro CT, et al. Stable infection of primates with Trypanosoma cruzi I and II. Parasitology. 2006;133:603-11.

24. Lisboa CV, Xavier SC, Herrera HM, Jansen AM. The ecology of the Trypanosoma cruzi transmission cycle: dispersion of zymodeme 3 (Z3) in wild hosts from Brazilian biomes. Vet Parasitol. 2009;165:19-24.

25. Lisboa CV, Monteiro RV, Martins AF, Xavier SC, Lima V dos S, Jansen AM. Infection with Trypanosoma cruzi Tcll and Tcl in free-ranging population of lion tamarins (Leontopithecus spp.): an 11-year follow-up. Mem Inst Oswaldo Cruz. 2015;110:394-402.

26. Vaz VC, D'Andrea PS, Jansen AM. Effects of habitat fragmentation on wild mammal infection by Trypanosoma cruzi. Parasitology. 2007;134:1785-93.

27. Herrera HM, Lisboa CV, Pinho AP, Olifiers N, Bianchi RC, Rocha FL, et al. The coati (Nasua nasua, Carnivora, Procyonidae) as a reservoir host for the main lineages of Trypanosoma cruzi in the Pantanal region, Brazil. Trans R Soc Trop Med Hyg. 2008;102:1133-9.

28. Roque ALR, Xavier SCC, Rocha MG, Duarte AC, D'Andrea PS, Jansen AM. Trypanosoma cruzi transmission cycle among wild and domestic mammals in three areas of orally transmitted Chagas disease outbreaks. Am J Trop Med Hyg. 2008;79:742-9.

29. Roque ALR, Xavier SCC, Gerhardt M, Silva MFO, Lima VS, D'Andrea PS, et al. Trypanosoma cruzi among wild and domestic mammals in different areas of the Abaetetuba municipality (Pará State, Brazil), an endemic Chagas disease transmission area. Vet Parasitol. 2013;193:71-7.

30. Alves FM, Olifiers N, Bianchi R de C, Duarte AC, Cotias PM, D'Andrea PS, et al. Modulating variables of Trypanosoma cruzi and Trypanosoma evansi transmission in free-ranging coati (Nasua nasua) from the Brazilian Pantanal region. Vector Borne Zoonotic Dis. 2011;11:835-41.

31. Orozco MM, Enriquez GF, Alvarado-Otegui JA, Cardinal MV, Schijman AG, Kitron U, et al. New sylvatic hosts of Trypanosoma cruzi and their reservoir competence in the humid Chaco of Argentina: a longitudinal study. Am J Trop Med Hyg. 2013;88:872-82.

32. Gürtler RE, Cardinal MV. Reservoir host competence and the role of domestic and commensal hosts in the transmission of Trypanosoma cruzi. Acta Trop. 2015;151:32-50.

33. Xavier SCC, Roque ALR, Lima V dos S, Monteiro KJL, Otaviano JCR, Silva LFCF, et al. Lower richness of small wild mammal species and Chagas disease risk. PLoS Negl Trop Dis. 2012;6:e1647.

34. Jansen AM, Roque ALR, Xavier SCC. Trypanosoma cruzi enzootic cycle: general aspects, domestic and synanthropic hosts and reservoirs. In: Telleria J, Tibayrenc M, editors. American Trypanosomiasis. 2nd ed. London: Elsevier 2017. p. 243-64.

35. Herrera HM, Dávila AM, Norek A, Abreu UG, Souza SS, D'Andrea PS, et al. Enzootiology of Trypanosoma evansi in Pantanal, Brazil. Vet Parasitol. 2004; 125:263-75

36. Austad NS. The adaptable opossum. Sci Am. 1988;258:98-104.

37. Rossi RV, Bianconi GV. Ordem Didelphimorphia. In: Reis NR, Perecchi AL, Pedro WA, Lima IP, editors. Mamíferos do Brasil. 2nd ed. Londrina: Edifurb; 2011. p. 31-69.

38. Jansen AM, Madeira FB, Deane MP. Trypanosoma cruzi infection in the opossum Didelphis marsupialis: absence of neonatal transmission and protection by maternal antibodies in experimental infections. Mem Inst Oswaldo Cruz. 1994:89:41-5.

39. Vieira EM, Camargo NF. Uso do espaço vertical por marsupiais brasileiros. In: Cáceres N, editor. Os marsupiais do Brasil: Biologia, ecologia e conservação. Campo Grande: Editora UFMS; 2012. p. 347-65.

40. Astúa D, Carvalho RA, Maia PF, Magalhães AR, Loretto D. First evidence of gregarious denning in opossums (Didelphimorphia, Didelphidae), with notes on their social behaviour. Biol Lett. 2015;11:20150307.

41. Carreira JC, Jansen AM, de Nazareth Meirelles M, Costa e Silva F, Lenzi HL. Trypanosoma cruzi in the scent glands of Didelphis marsupialis: the kinetics of colonization. Exp Parasitol. 2001;97:129-40.

42. Barros FB, de Aguiar Azevedo P. Common opossum (Didelphis marsupialis Linnaeus, 1758): food and medicine for people in the Amazon. J Ethnobio Ethnomed. 2014;10:65

43. Legey AP, Pinho AP, Xavier SC, Marchevsky R, Carreira JC, Leon LL, et al. Trypanosoma cruzi in marsupial didelphids (Philander frenata and Didelphis marsupialis): differences in the humoral immune response in natural and experimental infections. Rev Soc Bras Med Trop. 2003;36:241-8.

44. Dario MA, Lisboa CV, Costa LM, Moratelli R, Nascimento MP, Costa LP, et al. High Trypanosoma spp. diversity is maintained by bats and triatomines in Espírito Santo State, Brazil. PLoS One. 2017;12:e0188412.

45. Viola LB, Attias M, Takata CS, Campaner M, De Souza W, Camargo EP, et al. Phylogenetic analyses based on small subunit rRNA and glycosomal glyceraldehyde-3-phosphate dehydrogenase genes and ultrastructural characterization of two snake Trypanosomes: Trypanosoma serpentis n. sp. from Pseudoboa nigra and Trypanosoma cascavelli from Crotalus durissus terrificus. J Eukaryot Microbiol. 2009;56:594-602.

46. Meyers AC, Meinders M, Hamer SA. Widespread Trypanosoma cruzi infection in government working dogs along the Texas-Mexico border: discordant serology, parasite genotyping and associated vectors. PLoS Negl Trop Dis. 2017;11:e0005819.

47. Herrera HM, Rocha FL, Lisboa CV, Rademaker V, Mourão GM, Jansen AM. Food web connections and the transmission cycles of Trypanosoma cruzi and Trypanosoma evansi (Kinetoplastida, Trypanosomatidae) in the Pantanal Region, Brazil. Trans R Soc Trop Med Hyg. 2011;105:380-7. 
48. Mehrkens LR, Shender LA, Yabsley MJ, Shock BC, Chinchilla FA, Suarez J, et al. White-nosed coatis (Nasua narica) are a potential reservoir of Trypanosoma cruzi and other potentially zoonotic pathogens in Monteverde, Costa Rica. J Wild Dis. 2013:49:1014-8.

49. Martínez-Hernández F, Rendon-Franco E, Gama-Campillo LM, VillanuevaGarcía C, Romero-Valdovinos M, Maravilla P, et al. Follow up of natural infection with Trypanosoma cruzi in two mammal species, Nasua narica and Procyon lotor (Carnivora: Procyonidae): evidence of infection control? Parasit Vectors. 2014;7:405.

50. Bianchi RC, Campos RC, Xavier-Filho NL, Olifiers N, Gompper ME, Mourão GM. Intraspecific, interspecific, and seasonal differences in the diet of three mid-sized carnivores in a large Neotropical wetland. Acta Theriol. 2014;59:13-23.

51. Gompper ME, Decker DM. Nasua nasua. Mamm Species. 1998:580:1-9.

52. Emmons L. Neotropical Rainforest Mammals: A Field Guide. Chicago: The University of Chicago Press; 1997.

53. Hirsch BT, Maldonado JE. Familiarity breeds progeny: sociality increases reproductive success in adult male ring-tailed coatis (Nasua nasua). Mol Ecol. 2011;20:409-19.

54. de Lima JS, Rocha FL, Alves FM, Lorosa ES, Jansen AM, de Miranda Mourão G. Infestation of arboreal nests of coatis by triatomine species, vectors of Trypanosoma cruzi, in a large Neotropical wetland. J Vector Ecol. 2015;40: 379-85.

55. Santos FM, Jansen AM, Mourão G de M, Jurberg J, Nunes AP, Herrera HM. Triatominae (Hemiptera, Reduviidae) in the Pantanal region: association with Trypanosoma cruzi, different habitats and vertebrate hosts. Rev Soc Bras Med Trop. 2015:48:532-8.

56. Yoshida N. Molecular mechanisms of Trypanosoma cruzi infection by oral route. Mem Inst Oswaldo Cruz. 2009:104:101-7.

57. Flynn JJ, Wyss AR. Recent advances in South American mammalian paleontolgy. Trends Ecol Evol. 1998;13:449-54.

58. Bond M, Tejedor MF, Campbell KE Jr, Chornogubsky L, Novo N, Goin F. Eocene primates of South America and the African origins of New World monkeys. Nature. 2015;520:538-41.

59. Monteiro RV, Baldez J, Dietz J, Baker A, Lisboa CV, Jansen AM. Clinical, biochemical, and electrocardiographic aspects of Trypanosoma cruzi infection in free-ranging golden lion tamarins (Leontopithecus rosalia). J Med Primatol. 2006:35:48-55.

60. Rylands AB, Mittermeier RA, Bezerra BM, Paim FP, Queiroz HL. Family Cebidae (squirrel monkeys and capuchins). In: Mittermeier R, Rylands AB, Wilson DE, editors. Handbook of the Mammals of the World, 3rd ed. Barcelona: Lynx; 2013. p. 348-89.

61. Nowak RM. Order Primates. In: Nowak RM, editor. Walker's Mammals of the World, vol. 1, 6th ed. Baltimore: Johns Hopkins University Press; 1999. p. 490-631.

62. Hutchins M, Thoney D, McDade M. Grzimek Animal Life Encyclopedia vol.14. Detroit: Thomson-Gale; 2004

63. Molyneux DH. Evolution of the Trypanosomatidae. Considerations of polyphyletic origins of mammalian parasites. In: Leishmania. Taxonomie et Phylogénie. Applications éco-épidémiologiques. Montpellier: CNRS, INSERM, IMEEE; 1986. p. 231-40

64. Hamilton PB, Teixeira MM, Stevens JR. The evolution of Trypanosoma cruzi: the 'bat seeding' hypothesis. Trends Parasitol. 2012;28:136-41.

65. Thomas ME, Rasweiler JJ, D'Alessandro A. Experimental transmission of the parasitic flagellates Trypanosoma cruzi and Trypanosoma rangeli between triatomine bugs or mice and captive Neotropical bats. Mem Inst Oswaldo Cruz. 2007;102:559-65.

66. Dario MA, Moratelli R, Schwabl P, Jansen AM, Llewellyn MS. Small subunit ribosomal metabarcoding reveals extraordinary trypanosomatid diversity in Brazilian bats. PLoS Negl Trop Dis. 2017;11:e0005790.

Ready to submit your research? Choose BMC and benefit from:

- fast, convenient online submission

- thorough peer review by experienced researchers in your field

- rapid publication on acceptance

- support for research data, including large and complex data types

- gold Open Access which fosters wider collaboration and increased citations

- maximum visibility for your research: over $100 \mathrm{M}$ website views per year

At BMC, research is always in progress.

Learn more biomedcentral.com/submissions 